Review

\title{
A Review on the Performance of Concrete Containing Non-Potable Water
}

\author{
Babar Ali ${ }^{1}\left(\mathbb{D}\right.$, Rawaz Kurda ${ }^{2,3,4, *(\mathbb{D})}$, Jorge de Brito ${ }^{4, *(\mathbb{D})}$ and Rayed Alyousef ${ }^{5}(\mathbb{D})$ \\ 1 Department of Civil Engineering, COMSATS University Islamabad, Sahiwal Campus, \\ Sahiwal 57000, Pakistan; babar.ali@cuisahiwal.edu.pk \\ 2 Department of Highway Engineering, Technical Engineering College, Erbil Polytechnic University, \\ Erbil 44001, Iraq \\ 3 Scientific Research and Development Center, Nawroz University, Duhok 42001, Iraq \\ 4 CERIS, Civil Engineering, Architecture and Georresources Department, Instituto Superior Técnico, \\ Technical University of Lisbon, Av. Rovisco Pais, 1049-001 Lisbon, Portugal \\ 5 Department of Civil Engineering, College of Engineering, Prince Sattam Bin Abdulaziz University, \\ Alkharj 16273, Saudi Arabia; r.alyousef@psau.edu.sa \\ * Correspondence: Rawaz.kurda@tecnico.ulisboa.pt (R.K.); jb@civil.ist.utl.pt (J.d.B.)
}

Citation: Ali, B.; Kurda, R.; Brito, J.d.; Alyousef, R. A Review on the Performance of Concrete Containing Non-Potable Water. Appl. Sci. 2021, 11,6729. https://doi.org/10.3390/ app11156729

Academic Editor: Doo-Yeol Yoo

Received: 1 July 2021

Accepted: 19 July 2021

Published: 22 July 2021

Publisher's Note: MDPI stays neutral with regard to jurisdictional claims in published maps and institutional affiliations.

Copyright: (c) 2021 by the authors. Licensee MDPI, Basel, Switzerland. This article is an open access article distributed under the terms and conditions of the Creative Commons Attribution (CC BY) license (https:// creativecommons.org/licenses/by/ $4.0 /)$.

\begin{abstract}
Construction industries consume huge amounts of potable water during activities such as washing of aggregates, stone crushing, manufacturing, and curing of concrete, mortars, grouts, and wetting of masonry bricks. It is also responsible for wastewater generated during the finishing and cleaning of buildings and construction equipment. Therefore, the water-footprint of construction industry cannot be ignored to reach the state-of-the art sustainability. This study reviewed the technical properties of construction materials made with non-potable water (NPW), i.e., domestic and industrial sewage. The study identified the positive and negative effects of non-potable water on the fresh- and hardened-state properties of concrete. This study also identified the gaps in the literature that can be analysed in order to produce reliable information related to the use of different types of NPW on the properties of concrete.
\end{abstract}

Keywords: sustainability; wastewater; recycled; non-potable water; fresh properties; mechanical properties; durability

\section{Introduction}

Depletion of fresh water resources has increased due to climate changes, urbanization and industrialization [1,2]. Extraction of fresh water more than its natural supply has also increased concerns for sustainability. With the increasing demand for new infrastructure accompanying massive urbanization, the production of concrete and other building materials has increased enormously over the previous 50 years, with per capita growth rates higher than that of the population [3,4]. Due to the advantages of low cost and formability, concrete has experienced massive growth in its demand compared to other construction materials. Fresh water plays an important role in the different phases of concrete production and construction, i.e., aggregates cleaning, mixing, and curing of concrete, and cleaning of machinery and batching plants. Miller et al. [1] reported that $9 \%$ industrial extraction of fresh water is used by concrete industry, which accounts for up to $1.7 \%$ of the total extraction of fresh water.

The concrete industry can be considered one of the largest water-consuming sectors. As reported in [5], about 150 litres of water are needed per $\mathrm{m}^{3}$ of concrete. This value can increase to 500 litres per $\mathrm{m}^{3}$ of concrete by considering washing and losses during the production and transportation stages of concrete [6]. The wastewater (WW) generated by this activity can be considered a hazardous substance due to the presence of heavy metals and its high $\mathrm{pH}$ [7]. Furthermore, mandatory chemical boundaries, other limits, 
and general guidance on the type and amount of impurities of concrete mixing water are collected in [8].

To overcome the above issue, some studies suggest that, apart from potable water, treated heavy industry [9], treated palm-oil mill [9], fertilizer factory [10], reverse osmosis filter [11], polished filter [12], sugar factory [10,11], stone slurry [13], tanning industry [13], polyvinyl acetate [14], textile factory [10] and service station [10] WW can be used as mixing water in concrete. Nevertheless, studies on this path are still very scarce. Additionally, there is not an extensive review study to show the effect of different types and various incorporation ratios of WW on the performance of concrete.

Accordingly, this study focused on the mentioned gaps and collected all relevant studies on treated and untreated WW as mixing water in concrete. Furthermore, the focus of this study is mainly on the effect of WW as "mixing water" rather than its effect as curing water. In addition, some of the properties such as carbonation have not been considered because there were not many reliable sources.

\section{Methodology}

As mentioned above, the main objective of this study is to find the effect of WW (treated and untreated) on the performance of concrete. Thus, an extensive literature review was performed to collect the studies that use WW as "mixing water" in concrete [6,9-39]. As shown in Table 1, different types of WW have been used in concrete and their effects on the fresh, mechanical, and durability properties of concrete were considered. Regarding the content of non-conventional water used in concrete, $2 / 3$ of the studies investigated concrete made with NPW as $100 \%$ replacement of potable water while others studied concrete with different replacement levels of the potable water with NPW (mostly $25 \%$, $50 \%, 75 \%$ and $100 \%$ ).

In order to identify the effect of each selected NPW, their chemical and physical properties were studied in Section 3. This section was needed to understand their effects on the performance of concrete in terms of physical and chemical changes. After that, fresh properties such as slump (Section 4.1), setting time (Section 4.2) and air content (Section 4.3) and hardened properties such as compressive strength (Section 5.1), tensile strength (Section 5.2), hardened density (Section 5.3), water absorption (Section 5.4) and chloride ion penetration (Section 5.5) have been studied.

Table 1. Tests and type of WW used in concrete based on the selected studies.

\begin{tabular}{|c|c|c|c|c|c|c|}
\hline Study No. & Authors & Types of Water & $\begin{array}{c}\text { Incorporation } \\
\text { Ratio (\%) }\end{array}$ & $\begin{array}{c}\text { Fresh } \\
\text { Properties }\end{array}$ & $\begin{array}{l}\text { Mechanical } \\
\text { Properties }\end{array}$ & $\begin{array}{l}\text { Durability } \\
\text { and Others }\end{array}$ \\
\hline 1 & Tay and Yip (1986) & Treated WW & $0,25,50,75$ & - & CS & - \\
\hline \multirow{5}{*}{2} & \multirow{5}{*}{ Raza et al. (2021) } & Untreated WW & 0 and 100 & - & CS, ST & $\begin{array}{c}\text { WA, } \\
\mathrm{H}_{2} \mathrm{SO}_{4}-\mathrm{AACiP}\end{array}$ \\
\hline & & Fertilizer factory WW & 1 and 100 & - & CS & $\mathrm{WA}, \mathrm{H}_{2} \mathrm{SO} 4-\mathrm{AA}$ \\
\hline & & Textile factory WW & 2 and 100 & - & CS & $\mathrm{WA}, \mathrm{H}_{2} \mathrm{SO}_{4}-\mathrm{AA}$ \\
\hline & & Sugar factory WW & 3 and 100 & - & CS & $\mathrm{WA}, \mathrm{H}_{2} \mathrm{SO}_{4}-\mathrm{AA}$ \\
\hline & & Service station WW & 4 and 100 & - & CS & $\mathrm{WA}, \mathrm{H}_{2} \mathrm{SO}_{4}-\mathrm{AA}$ \\
\hline 3 & Ahmed et al. (2021) & Treated WW & 0 and 100 & - & CS, ST & $\mathrm{ER}, \mathrm{CiP}, \mathrm{D}_{\mathrm{nnsm}}$ \\
\hline \multirow{3}{*}{4} & \multirow{3}{*}{$\begin{array}{l}\text { Al-ghusain and Terro } \\
\qquad(2003)\end{array}$} & Preliminary treated WW & 0 and 100 & ST & CS & HD \\
\hline & & Secondary treated WW & 1 and 100 & ST & CS & HD \\
\hline & & Tertiary treated WW & 2 and 100 & ST & CS & HD \\
\hline 5 & Alenezi (2010) & Treated WW & $0,25,50,75,100$ & - & CS & $\mathrm{CiP}$ \\
\hline 6 & $\begin{array}{l}\text { Elchalakani and } \\
\text { Elgaali (2012) }\end{array}$ & $\begin{array}{l}\text { Wet recycling process } \\
\text { WW }\end{array}$ & $0,25,50,75,100$ & - & CS, ST, FS & WA, CiP, WAC \\
\hline \multirow[b]{2}{*}{7} & Sultan and Islam & Untreated WW & 100 & ST, SL & CS & UPV \\
\hline & $(2018)$ & Treated WW & 100 & ST, SL & CS & - \\
\hline 8 & Gadzama et al. (2015) & Untreated WW & 75,100 & ST & CS & - \\
\hline 9 & Tay (1989) & Treated WW & - & ST, SL & CS & WA, HD \\
\hline 10 & $\begin{array}{l}\text { El-Nawawy and } \\
\text { Ahmad (1991) }\end{array}$ & Treated WW & $\begin{array}{c}0,20,40,60,80 \\
100\end{array}$ & ST & CS, ST & - \\
\hline \multirow{2}{*}{11} & Peighambarzadeha & Untreated WW & - & ST, SL & - & - \\
\hline & et al. (2019) & Treated WW & - & ST, SL & - & - \\
\hline
\end{tabular}


Table 1. Cont.

\begin{tabular}{|c|c|c|c|c|c|c|}
\hline Study No. & Authors & Types of Water & $\begin{array}{l}\text { Incorporation } \\
\text { Ratio (\%) }\end{array}$ & $\begin{array}{c}\text { Fresh } \\
\text { Properties }\end{array}$ & $\begin{array}{l}\text { Mechanical } \\
\text { Properties }\end{array}$ & $\begin{array}{l}\text { Durability } \\
\text { and Others }\end{array}$ \\
\hline \multirow{7}{*}{12} & \multirow{7}{*}{ Al-Joulani (2015) } & $5 \%$ salt & 0 and 100 & SL & $\mathrm{CS}, \mathrm{ST}$ & WA \\
\hline & & $10 \%$ salt & 0 and 100 & SL & $\mathrm{CS}, \mathrm{ST}$ & WA \\
\hline & & $5 \%$ oil & 0 and 100 & SL & $\mathrm{CS}, \mathrm{ST}$ & WA \\
\hline & & $10 \%$ oil & 0 and 100 & SL & CS, ST & WA \\
\hline & & Treated WW & 0 and 100 & SL & $\mathrm{CS}, \mathrm{ST}$ & WA \\
\hline & & Stone slurry WW & 0 and 100 & SL & $\mathrm{CS}, \mathrm{ST}$ & WA \\
\hline & & Tanning industry WW & 0 and 100 & SL & $\mathrm{CS}, \mathrm{ST}$ & WA \\
\hline \multirow[b]{2}{*}{13} & \multirow{2}{*}{ Ghrair et al. (2016) } & Untreated WW & 0 and 100 & SL & CS & - \\
\hline & & Treated WW & 1 and 100 & SL & CS & - \\
\hline 14 & Chatveera et al. (2006) & Sludge WW & $\begin{array}{l}0,10,20,30,40 \\
\quad 60,80,100\end{array}$ & SL & CS, MS, FS & $\mathrm{H} 2 \mathrm{SO} 4-\mathrm{AASH}$ \\
\hline 15 & $\begin{array}{l}\text { Asadollahfardi et al. } \\
\text { (2016) }\end{array}$ & Treated WW & 0 and 100 & ST, SL & $\mathrm{CS}, \mathrm{ST}$ & WA, ER \\
\hline 16 & $\begin{array}{c}\text { Saxena and } \\
\text { Tembhurkar (2016) }\end{array}$ & Untreated WW & 0 and 100 & ST, SL, AC & CS, MS, FS & UPV, HD, CiP \\
\hline \multirow[t]{2}{*}{17} & Hassani et al. (2020) & Treated WW & - & - & - & $\mathrm{D}_{\mathrm{nnsm}}$ \\
\hline & & Primary treated WW & - & ST & CS, ST, FS & - \\
\hline \multirow[t]{2}{*}{18} & Shekarchi (2012) & Secondary treated WW & - & - & CS, ST, FS & - \\
\hline & & Tertiary treated WW & - & - & CS, ST, FS & - \\
\hline 19 & $\begin{array}{l}\text { Kaboosi and Emami } \\
\text { (2019) }\end{array}$ & Treated WW & $0,50,100$ & & CS & - \\
\hline 20 & $\begin{array}{l}\text { Ismail and Hashmi } \\
\text { (2011) }\end{array}$ & Polyvinyl acetate WW & 0 and 100 & SL & CS, FS & $\mathrm{HD}$ \\
\hline \multirow{3}{*}{21} & Saxena and & Treated WW & 0 and 100 & $\mathrm{SL}, \mathrm{AC}$ & CS, FS & WA, UPV, CiP \\
\hline & Tembhurkar (2019) & $\begin{array}{l}\text { Treated WW + bacterial } \\
\text { solution }\end{array}$ & 0 and 100 & $\mathrm{SL}, \mathrm{AC}$ & CS, FS & WA, CiP \\
\hline & & $\begin{array}{c}\text { Treated } \mathrm{WW}+\text { bacterial } \\
\text { solution }\end{array}$ & 0 and 100 & $\mathrm{SL}, \mathrm{AC}$ & CS, FS & WA, CiP \\
\hline \multirow{3}{*}{22} & Meena and Luhar & Secondary treated WW & 0 and 100 & SL & CS, FS & $D_{\text {nnsm }}$ \\
\hline & $(2018)$ & Tertiary treated WW & 0 and 100 & SL & CS, FS & $D_{\text {nnsm }}$ \\
\hline & & Treated WW & 0 and 100 & - & CS, ST, FS & - \\
\hline \multirow[t]{3}{*}{23} & Arooj et al. (2019) & Polish filtered WW & 0 and 100 & - & CS, ST, FS & - \\
\hline & & Bore water & 0 and 100 & - & CS, ST, FS & - \\
\hline & & Treated WW1 & 0 and 100 & - & - & - \\
\hline \multirow{3}{*}{24} & Babu and Ramana & Treated WW2 & 0 and 100 & - & - & - \\
\hline & $(2018)$ & Treated WW3 & 0 and 100 & - & - & - \\
\hline & & Treated WW4 & 0 and 100 & - & - & - \\
\hline \multirow{3}{*}{25} & $\begin{array}{c}\text { Daryaee and } \\
\text { Bijanvand (2021) }\end{array}$ & Reverse osmosis water & 0 and 100 & $\mathrm{ST}, \mathrm{SL}$ & $\mathrm{CS}, \mathrm{FS}$ & - \\
\hline & & River water & 0 and 100 & ST, SL & CS, FS & - \\
\hline & & Sugar factory WW & 0 and 100 & ST, SL & CS, FS & - \\
\hline \multirow{2}{*}{26} & & Untreated WW & 0 and 100 & & CS, FS & - \\
\hline & Mahasneh (2014) & Treated WW & 0 and 100 & & CS, FS & - \\
\hline 27 & $\begin{array}{l}\text { Asadollahfardi and } \\
\text { Mahdavi (2018) }\end{array}$ & Treated WW & 0 and 100 & ST, SL, AC & CS & WA, ER \\
\hline 28 & Yahyaei et al. (2020) & Treated WW & 0 and 100 & $\mathrm{SL}, \mathrm{AC}$ & $\mathrm{CS}, \mathrm{ST}$ & WA, ER, WAC \\
\hline 29 & Duarte et al. (2020) & Treated WW & $0,50,75,100$ & - & CS & - \\
\hline \multirow[t]{2}{*}{30} & Tonetti et al. (2019) & Treated WW & $0,50,75,100$ & - & CS & WA \\
\hline & & Heavy industry WW & 0 and 100 & ST, SL & CS & WAC \\
\hline \multirow[t]{2}{*}{31} & Noruzman (2012) & Treated WW & 0 and 100 & $\mathrm{ST}, \mathrm{SL}$ & CS & WAC \\
\hline & & Treated palm-oil WW & 0 and 100 & $\mathrm{ST}, \mathrm{SL}$ & CS & WAC \\
\hline 32 & Jabri et al. (2011) & Untreated WW & $0,25,50,100$ & SL & $\mathrm{CS}, \mathrm{ST}$ & WAC \\
\hline
\end{tabular}

ST-setting time ( $\mathrm{min}), \mathrm{SL}$-slump (mm), AC—air content (\%), CS—compressive strength (MPa), MS—modulus of elasticity (MPa), ST—splitting tensile strength (MPa), FS-flexural strength (MPa), WA-water absorption (\%), UPV—ultrasonic pulse velocity (m/s), ER-electrical resistivity $(\mathrm{Ohm}-\mathrm{m}), \mathrm{HD}$-hardened density $\left(\mathrm{kg} / \mathrm{m}^{3}\right)$, CiP—chloride ion permeability (Coulomb), $\mathrm{H}_{2} \mathrm{SO}_{4}-\mathrm{AA}-\mathrm{H}_{2} \mathrm{SO}_{4}$-acid

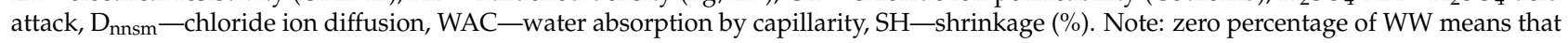
the study compared WW with conventional water. Minus sign $(-)$ means that there is no study on this path.

\section{Wastewater Characteristics}

One of the challenges of using WW (treated and untreated) in concrete can be its physical and chemical characteristics. Thus, the chemical and physical properties of the mixing water used in the studies considered in this work [6,9-39] were collected. As shown in Figure 1, there was a big scatter in the $\mathrm{pH}$, turbidity, alkalinity as $\mathrm{CaCO}_{3}$, hardness as $\mathrm{CaCO}_{3}$, total solids, total dissolved solids, total suspended solids, chloride, sulphate, 
conductivity, chemical oxygen demand and biological oxygen demand. In addition, the limits for substances of wastewater identified in ASTM T26-79 [40] are presented. The inconsistencies in their chemical and physical properties explain the variations of the performance of WW in concrete based on its type [13]. For example, the chance of corrosion may significantly increase with high chloride contents, and a high percentage of sulphate content may lead to sulphate attack and cracking in concrete [35]. These facts are explained in the next sections, namely the effect of different types of WW on the fresh- and hardenedstate properties of concrete.

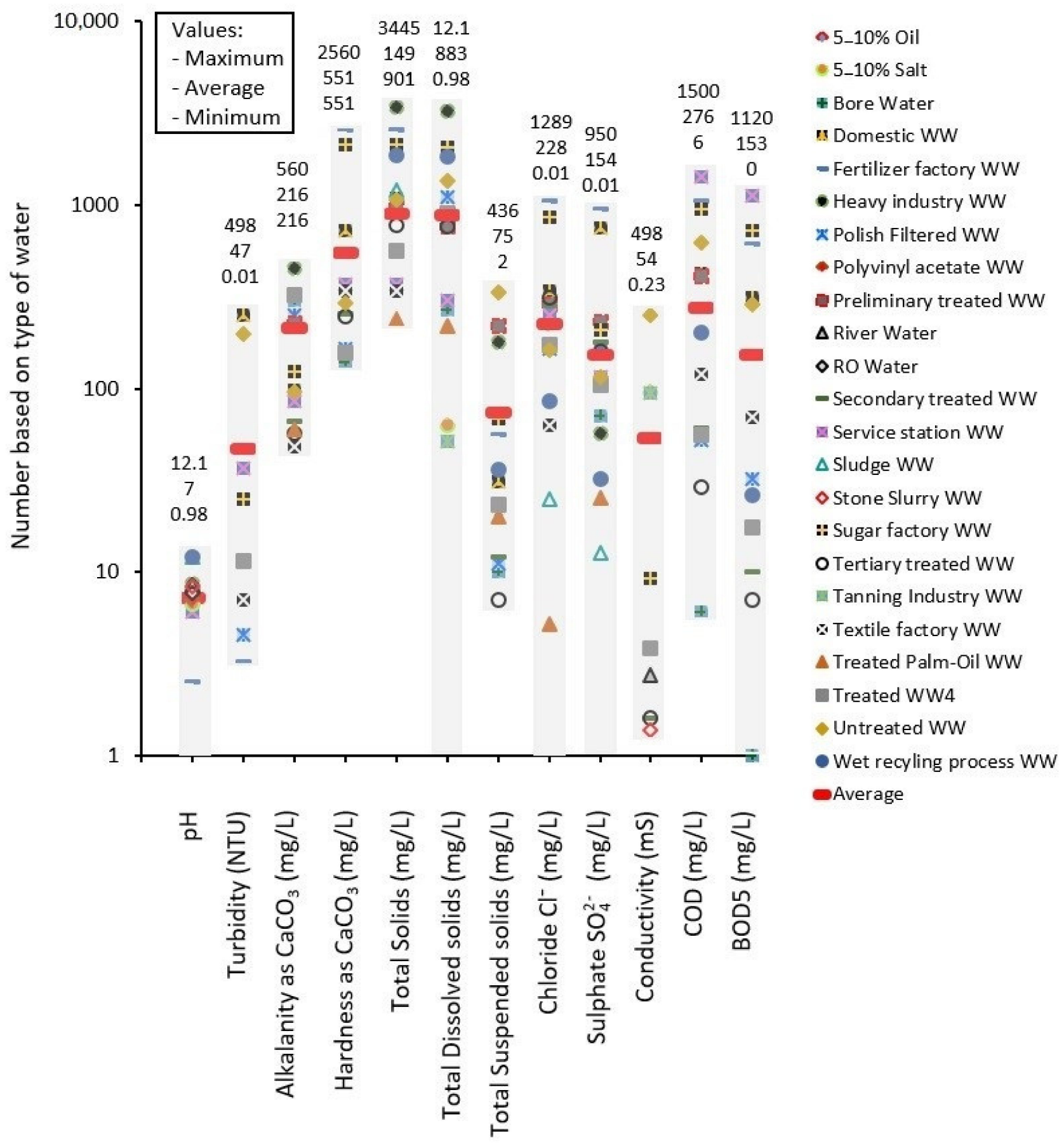

Figure 1. Average chemical and physical properties of non-conventional mixing water. 


\section{Fresh Properties}

\subsection{Slump}

Based on the results collected from these studies $[6,13,19,35]$, it can be said that the slump of concrete can be affected by the use of WW (Figure 2). Nevertheless, a reduction may be observed for some specific types of WW. For example, the study of Daryaee and Bijavand [11] showed that the slump of concrete can fall by $57 \%$ with the use of sugarcane WW. Based on their study, this happens because the electrical conduction (dissolved mineral contents) of the sugarcane WW is very high. The study showed that the slump of concrete increases by increasing the electrical conduction of water. The same reasons (low electrical conduction) can explain the high slump value with the use of reverse osmosis water or salt water [13]. In addition, the high slump value in concrete made with oil-water can be related to the fact that this water works as a surfactant [13]. In addition, Figure 3 shows that WW has less effect on the slump of concrete made with high $\mathrm{w} / \mathrm{c}$ than on mixes made with low $\mathrm{w} / \mathrm{c}$. Therefore, $\mathrm{WW}$ may not be recommended for concrete mixes made with low w/c.

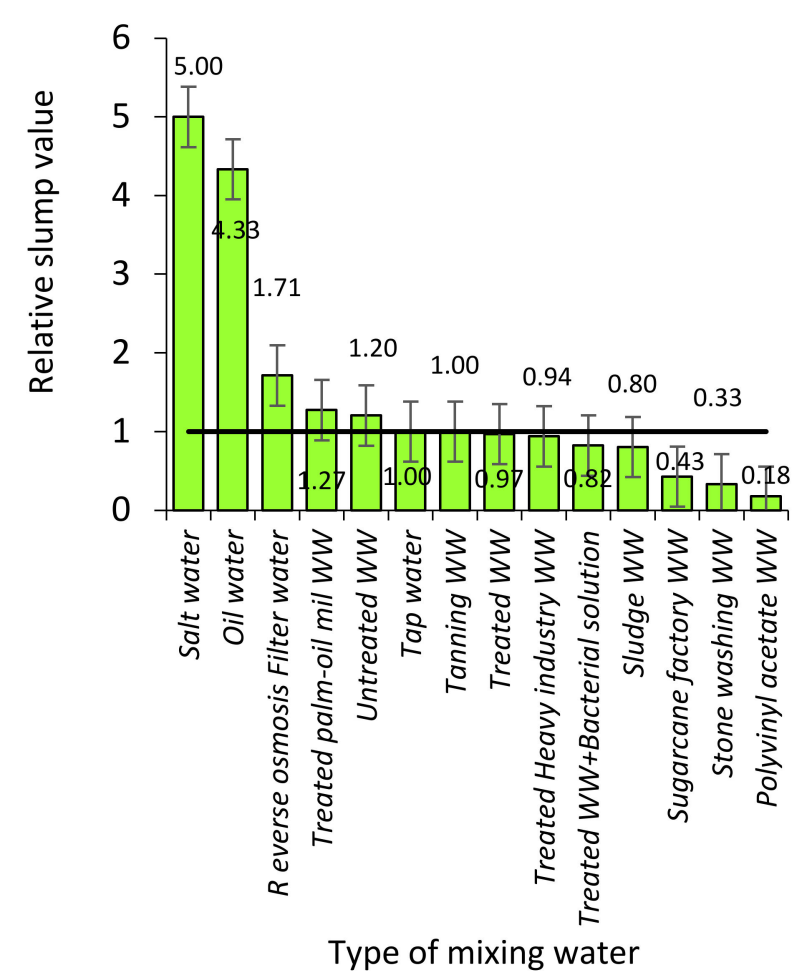

Figure 2. Effect of different types of WW on the slump of concrete.

\subsection{Setting Times}

Based on the results of the 12 studies considered in this investigation $[6,9,17-20,23$, $24,29,36,39,41]$, an increment in the initial and final setting time can be seen in all studies. Figure 4 shows the average value of the setting time from the selected studies and an increment can be clearly seen. This can be related to some factors, namely the total solid concentration of water (Figure 5). Reddy Babu et al. [42], Mindness et al. [43], and Gadzama et al. [18] reported that this happens due to the high percentage of such heavy metals as $\mathrm{Pb}, \mathrm{Cu}$ and $\mathrm{Zn}$ in water. Furthermore, the $\mathrm{pH}$ of water can also affect the results. The presence of organic matter in WW slightly increases its $\mathrm{pH}$, which may increase the setting times of cement [18]. 
Relative slump value

$\begin{array}{lll}\square 10-1.0 & \square 0.8-0.8 & \square 0.6=0.6 \\ \square 0.9-1.0 & \square 0.7-0.8 & \\ \square 0.9=0.9 & \square 0.7=0.7 & \\ \square 0.8=0.9 & \square^{0.6-0.7} & \end{array}$

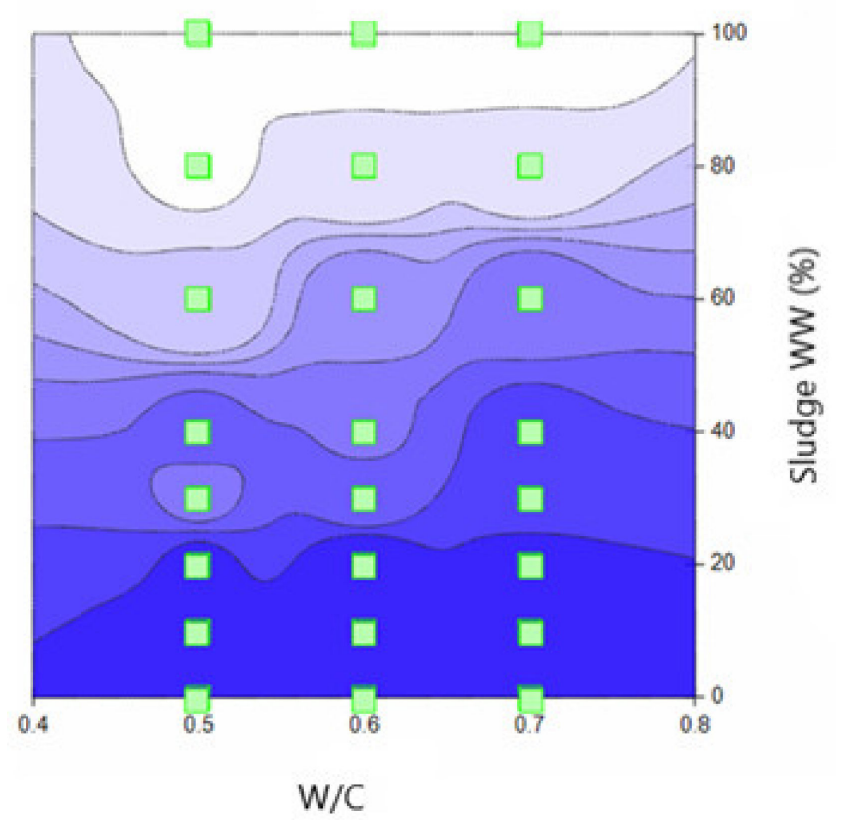

Figure 3. Effect of different incorporation ratios of WW on the slump of concrete made with various $\mathrm{w} / \mathrm{c}$.

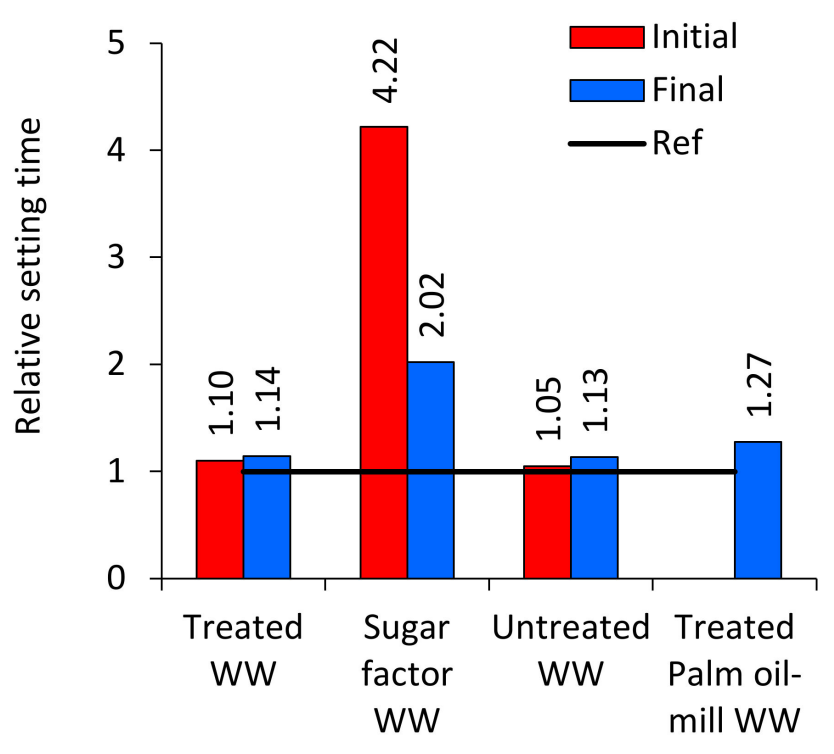

Type of water

Figure 4. Effect of different types of WW on the setting time of concrete. 


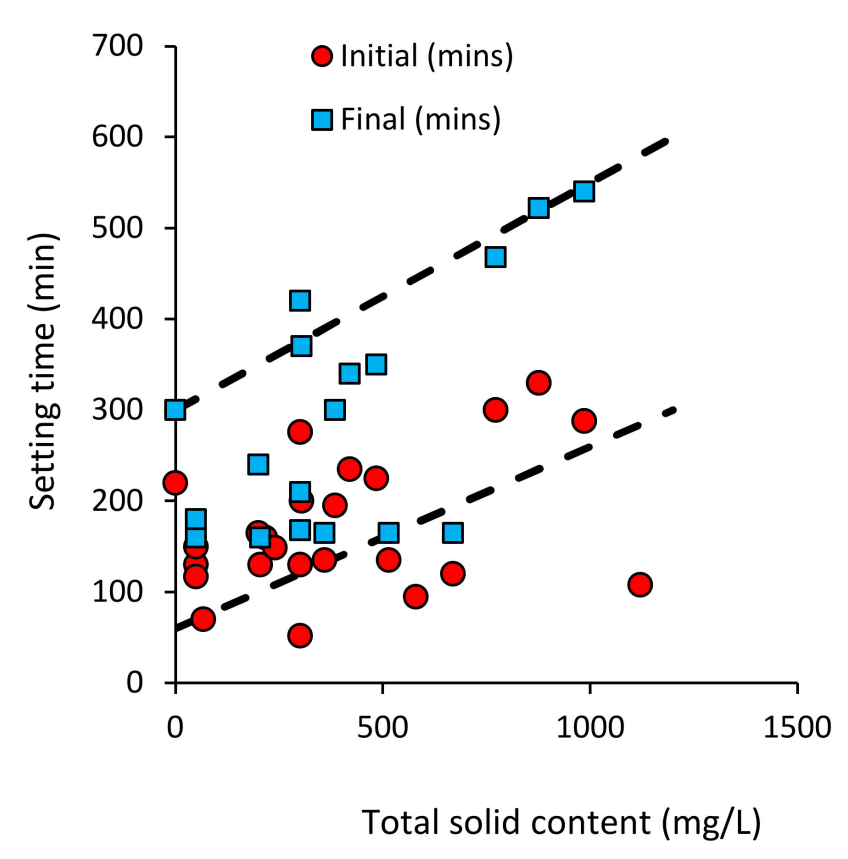

Figure 5. Effect of the total solid concentration on the setting time of concrete.

\subsection{Air Content}

Since the chemical composition of WW is different from that of tap water, reactions and more gas bubbles may be generated. Based on the studies of Saxena and Tembhurkar [24,27], Asadollahfardi and Mahdavi [31] and Yahyaei et al. [32], the air content of concrete increases (2-34\%) with the use of WW, unless it has been treated.

\section{Hardened Properties}

5.1. Compressive Strength

\subsubsection{Effect of Untreated WW}

The effect of untreated WW on compressive strength was reported in 8 studies [10, $16,18,21,24,26,29,30]$, as shown in Figure 6. In general, an approximate $0-20 \%$ decline in compressive strength was observed when potable water was replaced with untreated WW (non-potable). Gadzama et al. [18] studied the compressive strength of concrete with untreated WW, and they reported a decrease in early-age strength because of the presence of high amounts of organic matter. Raza et al. [10] reported that compressive strength decreased by $30 \%$ at full replacement of potable water with untreated WW. They blamed this reduction in compressive strength on the presence of high amounts of organic matter. Similarly, Mahasneh [30] reported a decline in early-age compressive strength due to the presence of high amounts of organic matter in untreated WW. Moreover, the strength gap between potable water and untreated WW concrete decreased as the age of curing increased beyond 28-days. It was also reported that treated WW concrete had higher strength than untreated WW concrete due to fewer impurities [30]. Some studies [9,24] reported an increase of $9-44 \%$ in the early-age strength with the use of untreated WW due to the presence of salts. 

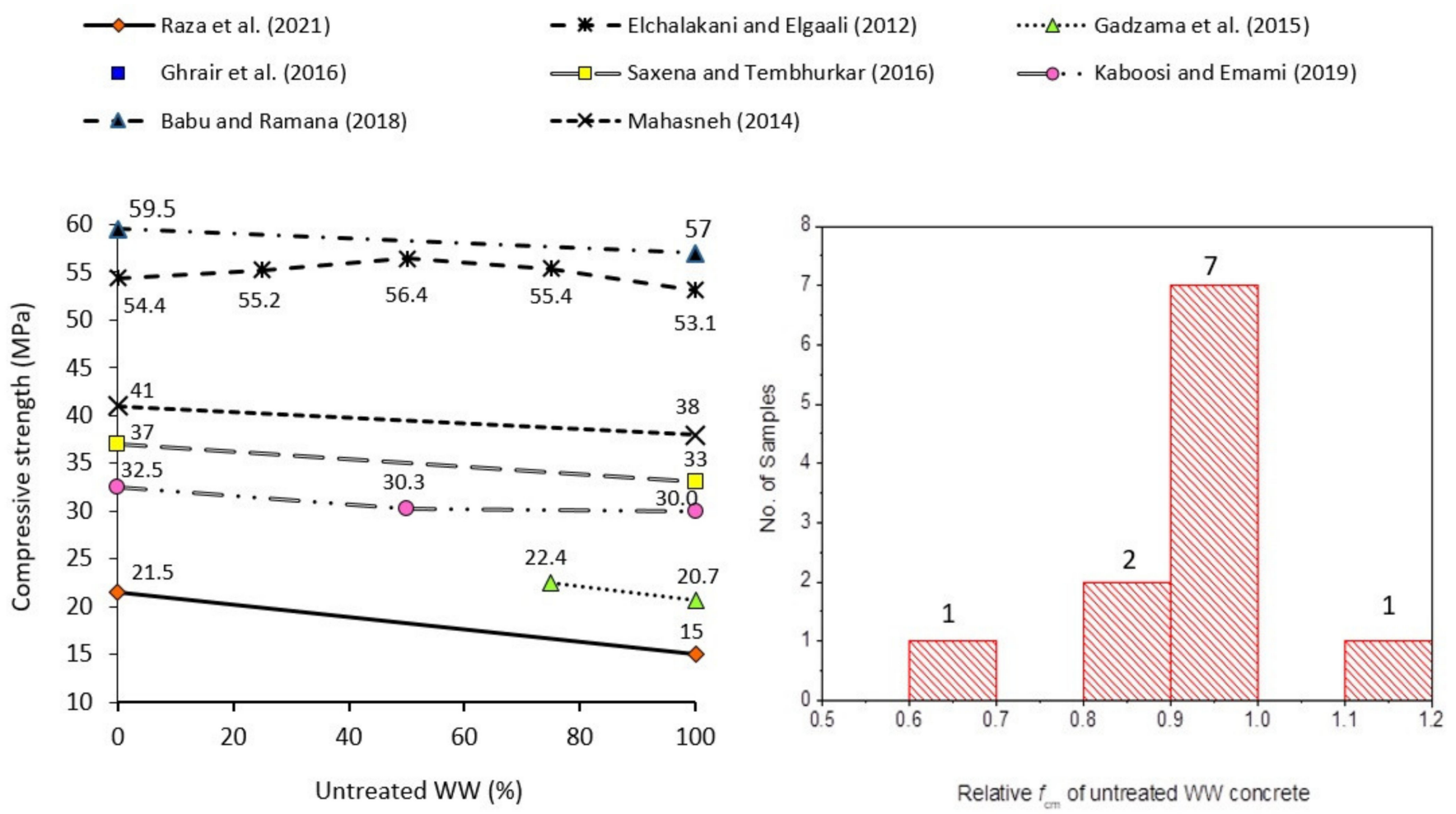

Figure 6. Effect of untreated WW on the compressive strength of concrete.

\subsubsection{Effect of Treated WW}

Compressive strength is one of the most important properties of concrete that is widely used for the design of concrete structures. The effect of treated WW content on the compressive strength of concrete, according to various studies $[9,12,13,15,20-22,27,28,30$, 31,33,35-38], is shown in Figure 7. Tay and Yip [19,37] studied the compressive strength of concrete with different contents of treated WW and reported insignificant changes with varying WW percentage. This was because the treated WW has impurities well below the limits recommended for water used for concreting purposes [44]. Similar results were reported in other five studies $[9,15,21,30,33]$. Organic matter may negatively influence the strength gain of concrete due to a low $\mathrm{pH}$. On the other hand, WW contains solid mineral particles, which might fill the voids and cause an improvement in the strength of concrete [9]. In short, WW contains constituents that show mixed effects on strength. Moreover, the presence of sodium chloride could also contribute positively to concrete. The early-age strength of concrete is positively affected by the chloride activator [45]. Sultana and Islam [17] also reported that early-age strength of treated WW mortar was higher than that of a potable water mortar.

The histogram in Figure 8 shows the plot between many samples investigated in the past studies and the range of relative compressive strength $\left(f_{\mathrm{cm}}\right)$ obtained using treated WW. It is shown that both positive and negative effects of treated WW were observed on the compressive strength. A total of 23 samples lie in the band of $0.8-1.1$, where 11 samples yielded compressive strength within the $0.9-1.0$ band. Based on the available evidence, it can be said more confidently that treated WW concrete will yield similar $f_{\mathrm{cm}}$ to that of potable water concrete. 


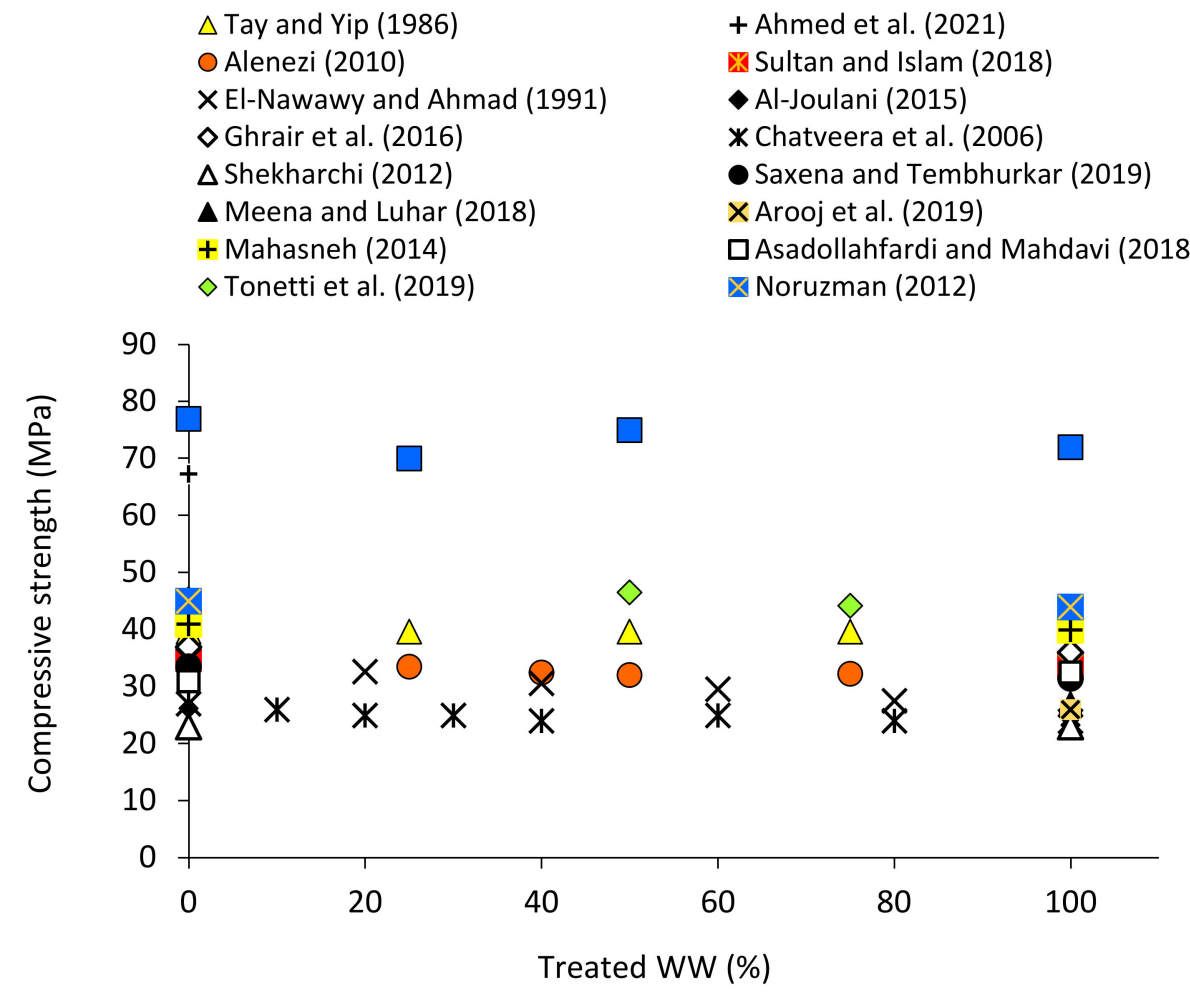

Figure 7. The effect of treated WW on the compressive strength of concrete reported in different studies.

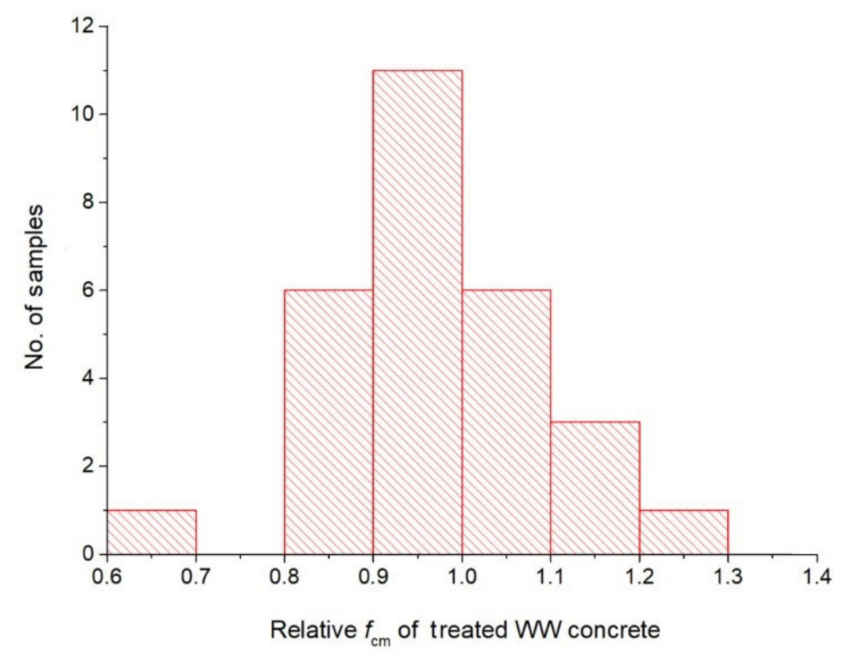

Figure 8. Histogram of relative compressive strength of concrete made with treated WW versus no. of occurrences.

\subsubsection{Effect of Various Types of Wastewaters on Compressive Strength}

The composition of WW depends on its source; therefore, the characteristics of WW concrete will significantly fluctuate if industrial and domestic WW are derived from different sources and demographics. The compressive strength of most WW concrete relative to potable water concrete reported in different studies is shown in Figure 9. It can be seen that both positive and negative effects of WW on the strength of concrete can be expected. Raza et al. [10] reported that textile factory WW show an increase in compressive strength, while sugar and fertilizer factory WW shows a minor effect on compressive strength. They reported that fluorides and bicarbonates present in textile WW react with alumina leading forming calcium fluoroaluminates that contribute to strength enhancement. 
Any evidence based on chemical and microstructural analysis is not documented yet. Due to the presence of activator salts in both fertilizer and textile WW, the early-age strength of concrete increased [10]. Al-Joulani [13] reported that WW containing $5 \%$ and $10 \%$ salts lead to higher strengths than potable water concrete at 28-days. However, no justifications were presented for this important development. On the other hand, a notable decline in compressive strength was observed when oil WW was used. Stone slurry WW improved the compressive strength by almost $20 \%$. This could be attributed to the high mineral content that acts as a filler and it may decrease the water/binder ratio. WW from the tanning industry reduced compressive strength by $7 \%$. As the tanning industry WW is highly acidic, it is expected to increase the strength-gaining period of concrete.

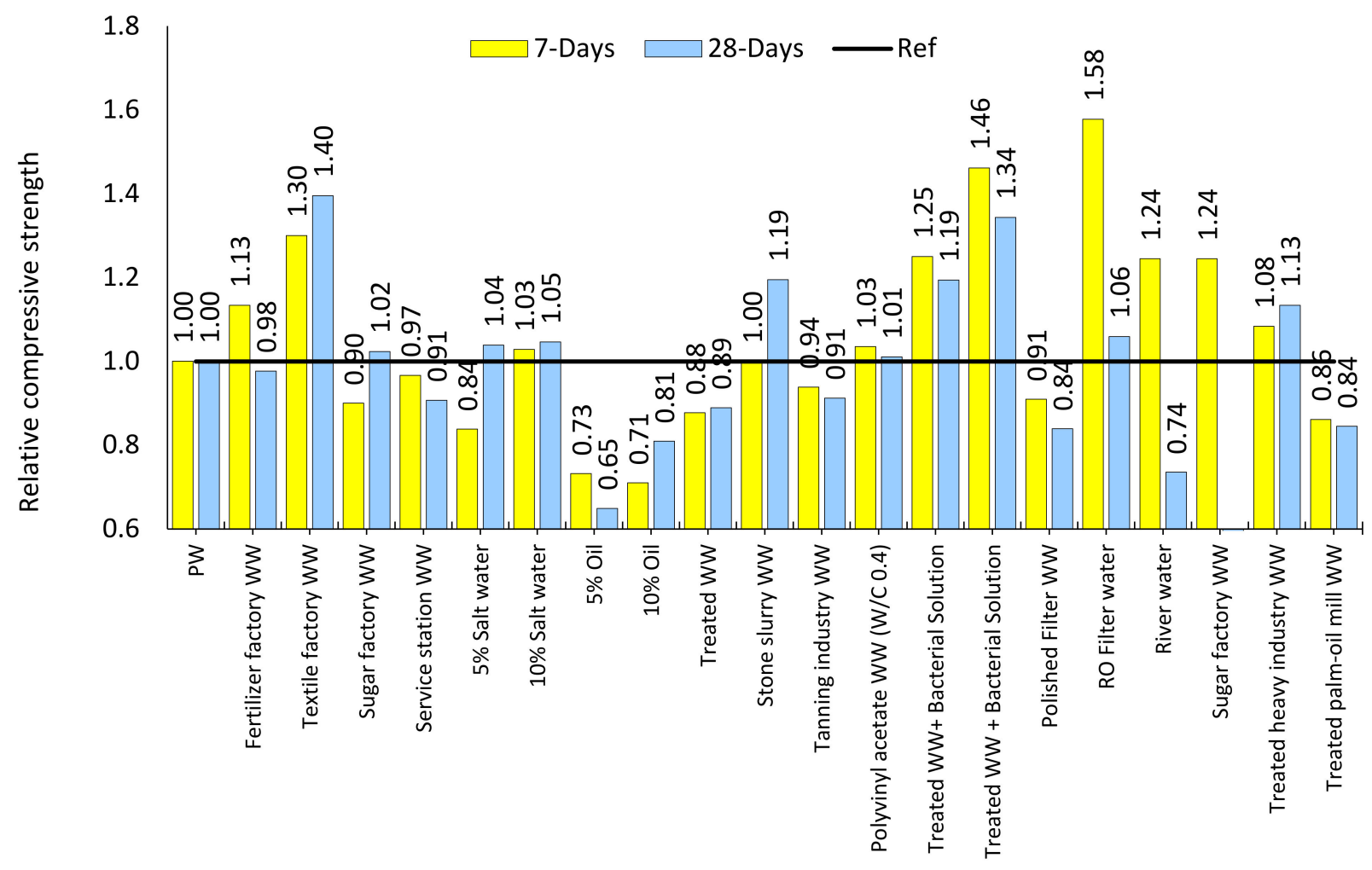

Figure 9. Compressive strength of different WW concrete relative to that of tap water or potable water concrete.

Ismail and Hashmi [14] reported that the replacement of potable water with polyvinyl acetate WW does not have adverse effects on compressive strength. Polyvinyl acetate WW concrete showed slightly higher compressive strength than potable water concrete at seven and twenty-eight days. It was hypothesized that polyvinyl acetate WW improved the density due to the lubrication effect of polymer particles that caused an improvement in compressive strength. Saxena and Tembhurkar et al. [27] reported that concrete made with WW mixed with bacterial solutions (Bacillus cereus) can yield 20\% higher compressive strength than concrete made with conventional potable water. The main reason for this behaviour was the formation of $\mathrm{CaCO}_{3}$ by bacterial filling the voids. Daryaee and Bijavand [11] studied concrete with reverse osmosis water, river water, and sugar factory WW. They reported that reverse osmosis water produced concrete with $6 \%$ higher strength than potable water concrete. River water reduced the compressive strength by $26 \%$. Sugar factory WW reduced the compressive strength by $40 \%$. However, no reason was presented for the detrimental effects of river water and sugar factory WW. Noruzaman et al. [9] studied concrete with heavy industry and palm-oil mill WW. They reported that heavy industry WW improved the compressive strength by $8-13 \%$ due to the presence of heavy solids and chlorides, while palm-oil mill WW contained organic impurities that reduced the 28-days compressive strength of concrete by $16 \%$. 


\subsection{Tensile Strength}

As per the available relevant literature [10,30], splitting tensile strength is reduced by $10-70 \%$ upon the replacement of potable water with untreated WW, depending on the type pollutants, as per Figure 10. Mahasneh et al. [30] reported that concrete with untreated WW had lower tensile strength than that of treated WW concrete. This was because the chemical properties or composition of treated WW were not far from those of potable water but were very different from those of untreated WW. Raza et al. [10] blamed the reduction of tensile strength on the high amounts of organic matter, as indicated by $\mathrm{BOD}_{5}$ and $\mathrm{COD}$ values (Figure 1).
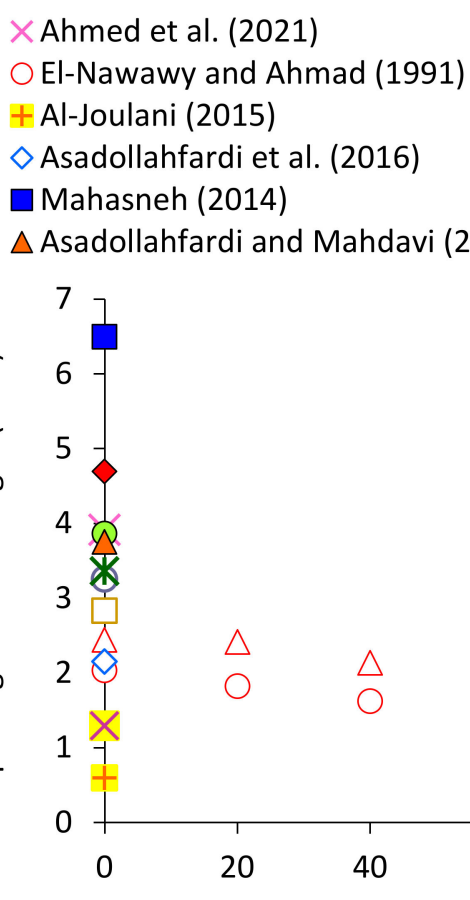

Ahmed et al. (2021)

$\triangle$ El-Nawawy and Ahmad (1991)

$\times$ Al-Joulani (2015)

$\square$ Arooj et al. (2019)

O Asadollahfardi and Mahdavi (2018)

* Asadollahfardi and Mahdavi (2018)

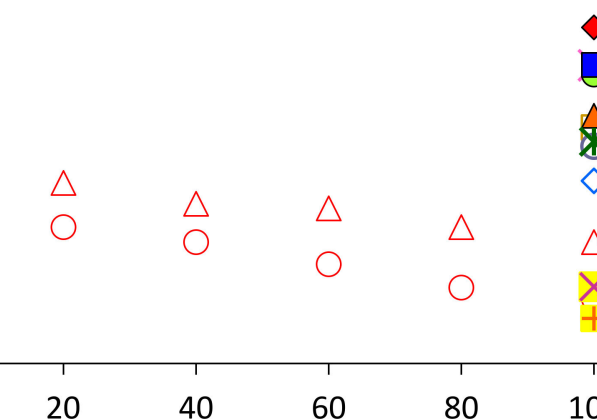

Treated WW (\%)

Figure 10. Effect of treated WW on the splitting tensile strength of concrete relative to that of potable water concrete.

The effect of treated WW on the splitting tensile strength of concrete, reported in the available literature, is shown in Figure 10. In most of the studies, the splitting tensile strength of concrete decreased with the replacement of potable water with treated WW. El-Nawawy and Ahmed [20] reported a large decline of 35-55\% in splitting tensile strength due to using treated WW. Mahasneh [30] reported a decrease of $40-70 \%$ in splitting tensile strength with the use of treated WW, while most of the studies $[12,13,23,31,32,38]$ showed that the splitting tensile strength of treated WW concrete was $80-110 \%$ of that of the corresponding potable water concrete. The variation in the reported effects of treated WW on tensile strength is huge because of the difference in methods and levels of treatment.

The effect of different types of WW on the splitting tensile strength of concrete relative to that of potable water concrete is shown in Figure 11. The lowest relative splitting tensile strength was observed with untreated WW. On average, untreated WW concrete showed about $25 \%$ lower tensile strength than potable water concrete, whereas treated WW concrete showed an average reduction of 5\% in tensile strength. The difference in tensile strength of concrete made with treated and untreated WW is mainly because of the presence of high organic matter in the latter. On the other hand, textile factory WW [10], polish filter water [12] and stone slurry WW [13] achieved 17-24\% higher tensile strength than the corresponding potable water concrete. The effect of oil WW was the same as that 
of untreated WW the tensile strength, while salty water showed effects similar to those of treated WW.

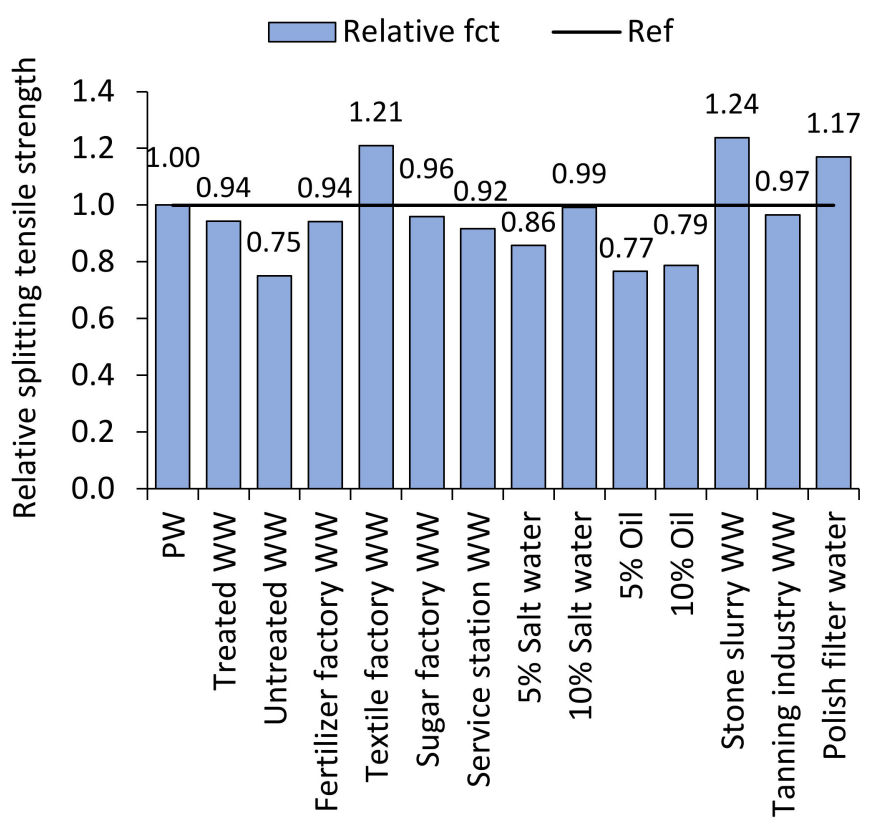

Figure 11. Effect of different types of WW on the splitting tensile strength of concrete relative to that of potable water concrete.

The relationship between splitting tensile strength $\left(f_{\mathrm{ct}}\right)$ and corresponding compressive strength $\left(f_{\mathrm{cm}}\right)$ values, reported in various studies [10,12,13,20,25,30-32,38], is shown in Figure 12. The relationship is derived without considering the shape and size effect of the testing samples due to lack of available studies. Moreover, the effect of WW type was also neglected in deriving the relationship.

As shown in Figure 12, the variation of $f_{\mathrm{ct}}$ with $f_{\mathrm{cm}}$ follows an almost similar trend as that of the Eurocode N-1992-1-1 [46]. The predicted relationship is not strong as the coefficient of determination $\left(R^{2}\right)$ is below 0.7 . The difference between the y-ordinate values of the predicted curve and the Eurocode curve is not significant; therefore, an established standard can be used to predict $f_{\mathrm{ct}}$ from $f_{\mathrm{cm}}$. The microstructural development affected by WW types is similarly reflected in $f_{\mathrm{ct}}$ and $f_{\mathrm{cm}}$, so both parameters can be correlated accurately with each other.

Despite the fact that there are not many studies regarding the effect of WW on the flexural strength of concrete, the available data referred that WW (treated and untreated) at almost all incorporation ratios reduces the flexural strength of concrete (Figure 13). Nevertheless, this reduction has not been noted at early ages of concrete. In addition, the relationship between compressive strength and flexural strength is poor (Figure 13). However, further studies require identifying the relationship between the flexural and compressive strengths. Chatveera et al. [22] reported that the bond strength between cement paste and aggregate was weaker when WW (e.g., sludge water) was used in concrete. 


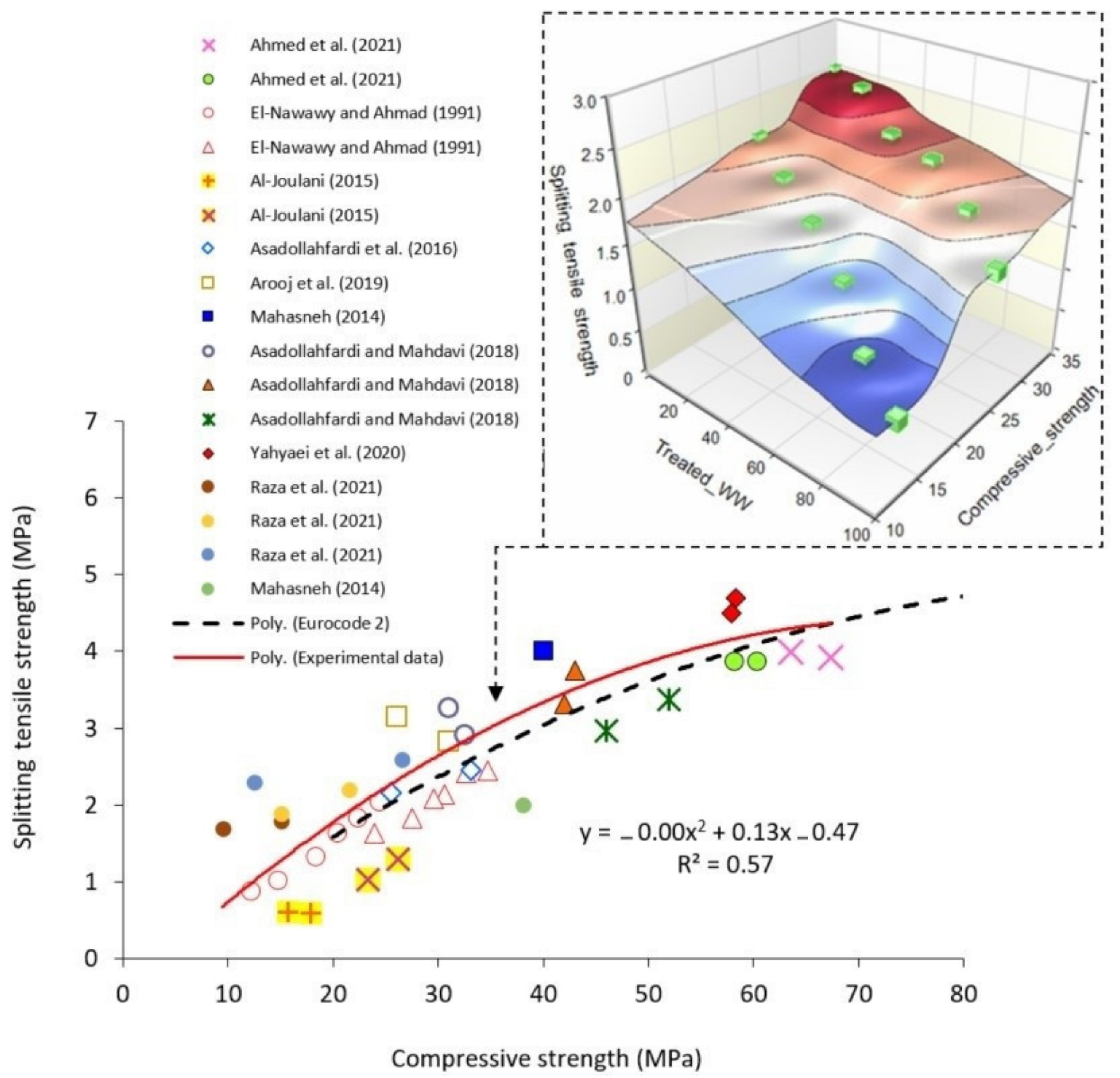

Figure 12. Relationship between compressive strength and splitting tensile strength.

\subsection{Hardened-State Density and Ultrasonic Pulse Velocity}

Tay [19] studied the density of concrete with various contents of treated WW. The density of tap water and WW concrete was the same for various contents of WW. This was because WW used in the production of concrete satisfied the tolerable chemical limits of water required for concreting [44]. Saxena and Tembhurkar [24] also concluded that the replacement of tap water with WW does not significantly change the density.

Ghusain et al. [39] studied the hardened-state density of concrete with preliminary, secondary, and tertiary treated WW, as per Figure 14. They reported a change of $5 \%$ in the density of concrete when the treatment quality of WW was increased. However, no reason was presented for such behaviour. Since primary-treated WW contains a higher solid content than tertiary-treated WW, it is hypothesized that the density of WW concrete decreased due to a decline in the solid content of WW. However, it cannot be explained with the available information why the density of tap water concrete was higher than that of WW concrete. Therefore, further research is recommended in this domain. 


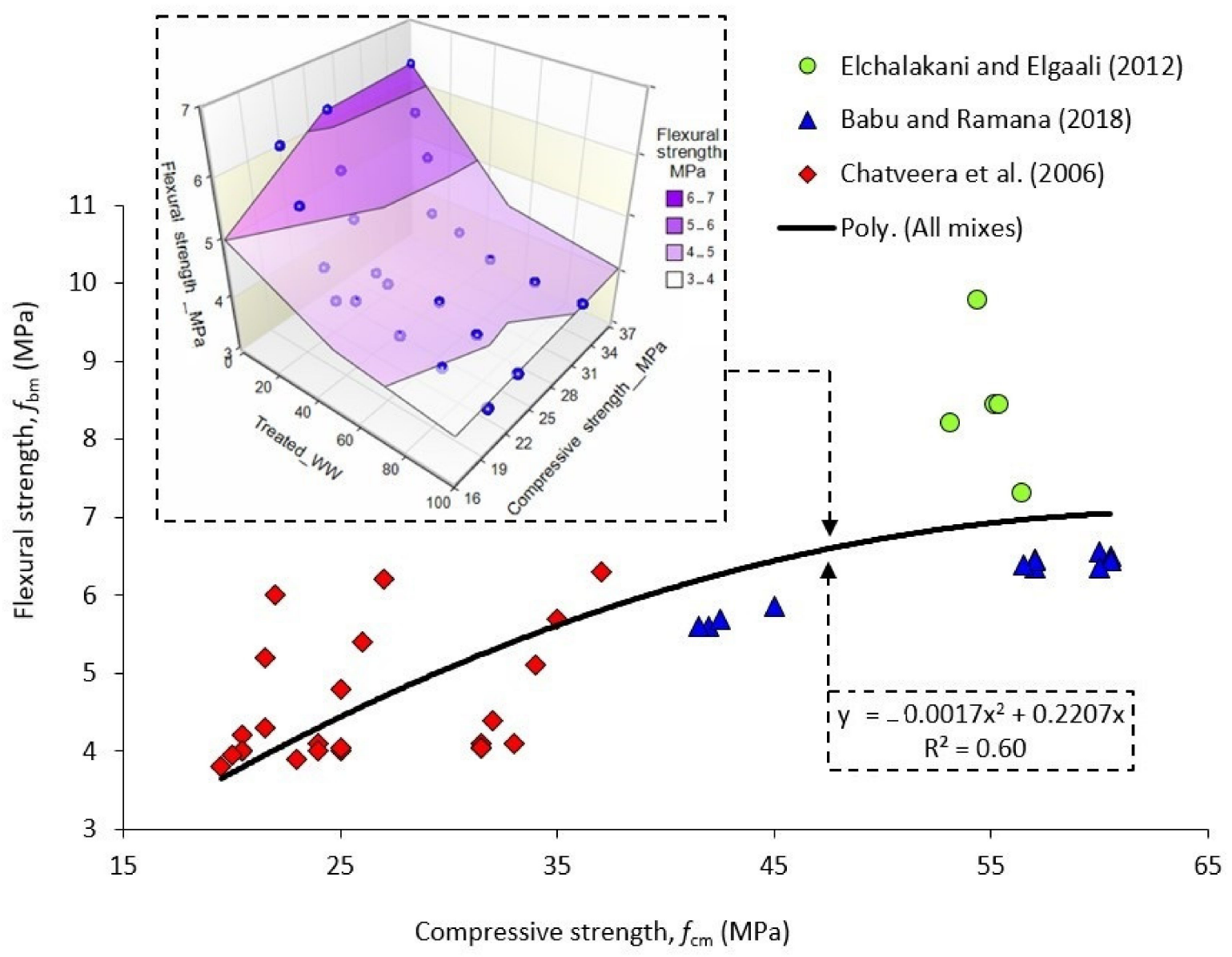

Figure 13. Relationship between compressive strength and flexural strength.

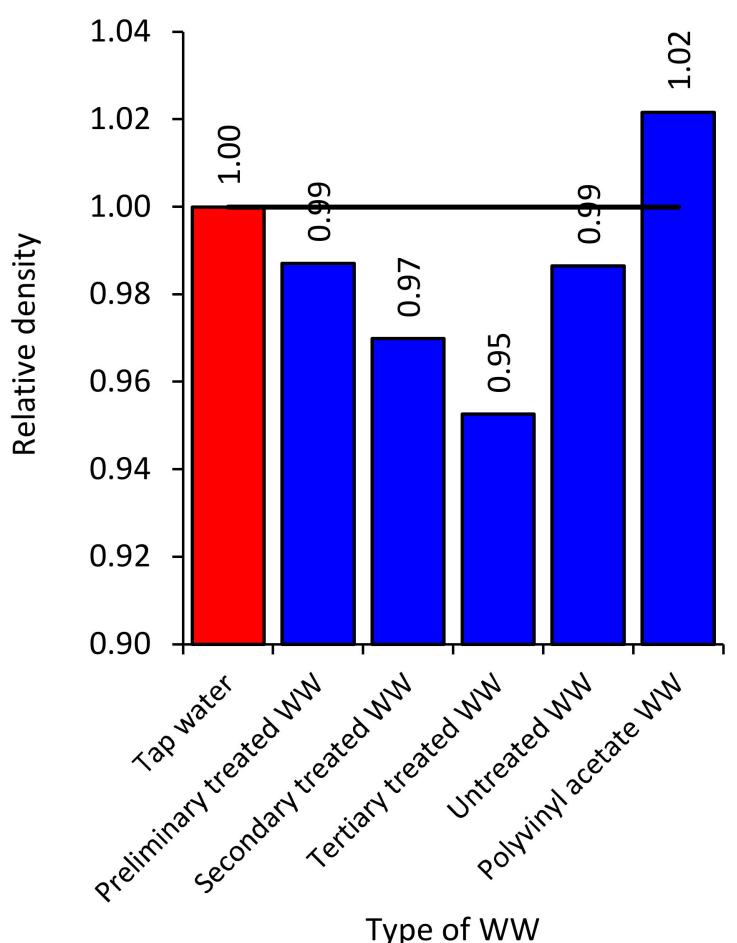

Figure 14. Effect of primary-, secondary- and tertiary-treated WW on the density of concrete [39]. 
A study reported an increase in the density of concrete when polyvinyl acetate WW fully replaced tap water. This was because polyvinyl acetate WW has a higher density (i.e., $1050 \mathrm{~kg} / \mathrm{m}^{3}$ ) than tap water. Figure 15 shows the average effect of different types of WW on the relative density of concrete derived from four studies $[14,19,24,39]$. From the available evidence, it is hard to pinpoint the effect of WW on the density of concrete.

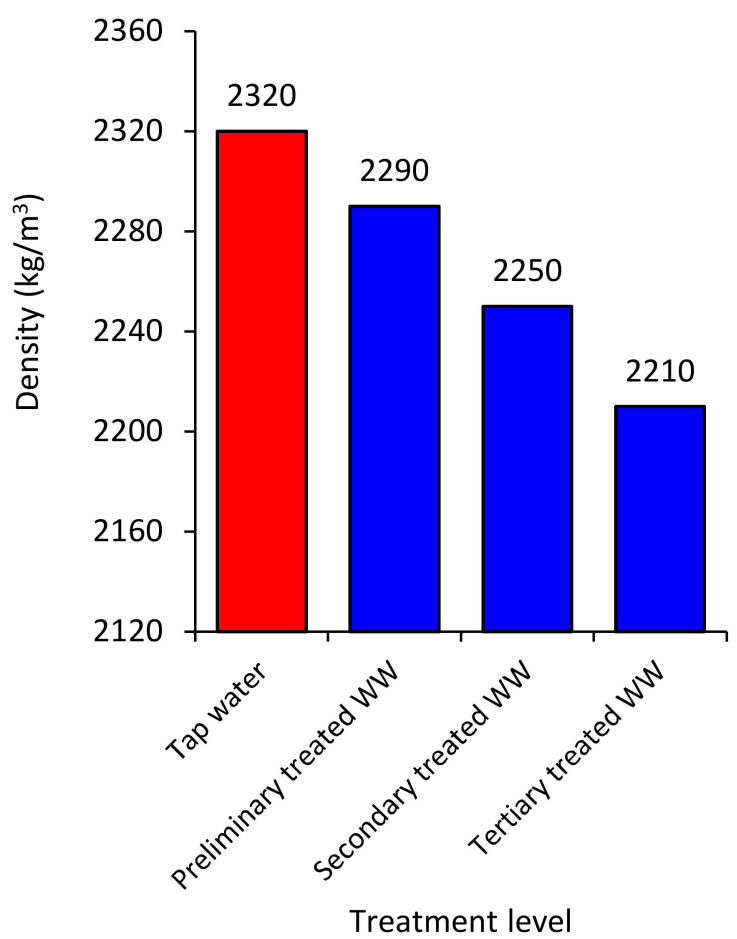

Figure 15. Average effect of different WW types on the relative density of concrete $[14,19,24,39]$.

As expected from the results of hardened density, the UPV of concrete decreases with the use of WW. For example, the study showed that the UPV of concrete falls by $3 \%, 4 \%$ and $11 \%$ (Figure 16). This can be explained by the same reasons concerning the hardened-state density and Section 5.4.

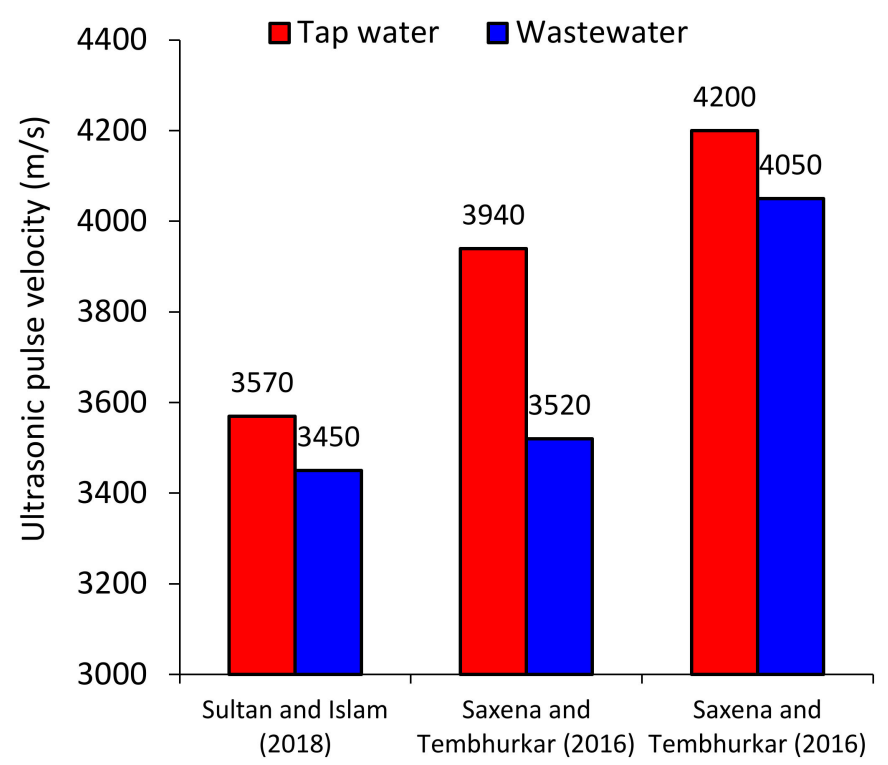

Figure 16. Effect of WW on the UPV of concrete. 


\subsection{Water Absorption Capacity}

Water absorption (WA) represents the permeable porosity of concrete. According to different studies $[13,19,23,31,32,34]$ that used different incorporation ratios $(25 \%, 50 \%$ and $100 \%$ ) of treated water, there is no big difference between the values of tap water concrete and treated WW concrete (Figure 17). As treated WW has fewer impurities and organic matter, it may not be harmful to the imperviousness of concrete.

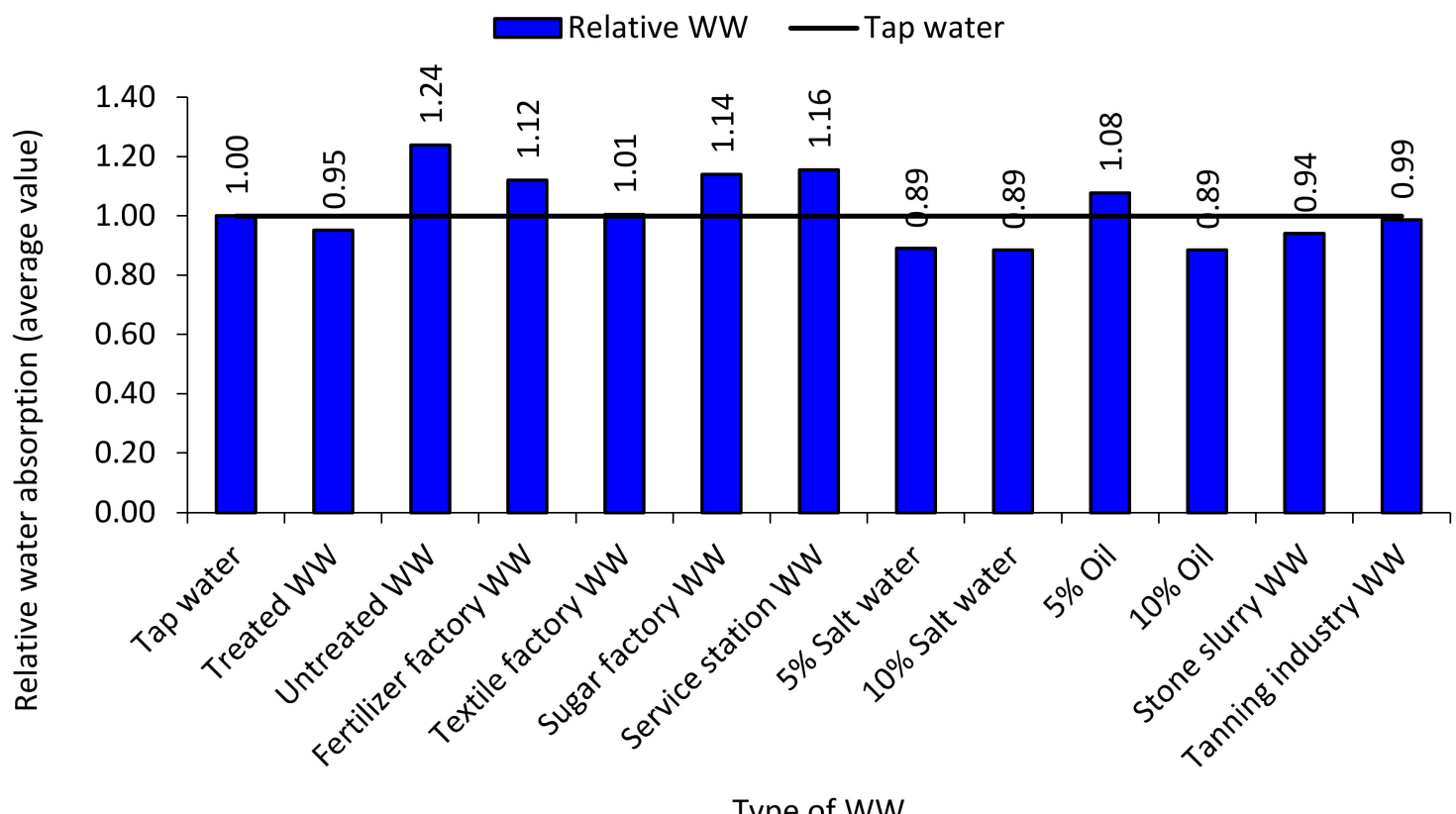

Type of WW

Figure 17. Effect of different types of WW on the water absorp + tion of concrete relative to that of potable water concrete.

Other studies $[10,16,24]$ used the same incorporation ratios of untreated water and showed that the water absorption of concrete increased up to $24 \%$ (Figure 17). In addition, in some cases, the water absorption of concrete decreased with the use of some specific WW. This can be related to the fact that the chloride quantity in WW was lower than that in potable water [47]. In addition, other studies reported that domestic sewerage WW contains a large amount of organic WW that causes the formation of a large number of small pores leading to increased water absorption [10]. These differences between types of WW can be clearly seen when the water absorption and strength of WW concrete are compared (Figure 18). The results show that there is a poor relationship between the two properties because some of the chemical properties may not directly affect some of the hydration products (e.g., chloride content), while they may affect the porosity of concrete due to the gas generated out of them during the early reaction of cement compounds with them.

\subsection{Chloride Penetration}

Two of the most important factors to evaluate the applicability of any WW materials in terms of durability are chloride ion penetration and carbonation. Studies regarding the effect of WW on the carbonation of concrete are very scarce. Therefore, we only focused on available data in the literature, namely studies on chloride ion penetration.

Figure 19 shows the relative chloride ion penetrability (based on the charge passed, in Coulomb) of concrete made with treated $[15,27,28,38]$ and untreated $[16,24]$ WW. The results show that chloride ion penetration increases by increasing the incorporation ratio of untreated WW (up to 33\%). Despite the fact that the evidence regarding the mentioned increment was not enough, it can be said that it happened because less hydration products will be formed with untreated WW, and relative to potable water, untreated WW has higher chloride ion content [16]. In general, the opposite conclusion can be seen in concrete 
made with treated WW. This mostly related to the fact that the sulphates and chlorides contents are specifically reduced in the treatment process of water to reduce the risk of concrete deterioration [16]. In addition, another study [10] reported that the low chloride ion penetration rate of treated WW concrete is related to the fact that the iron content of treated WW was lower than that of potable water.
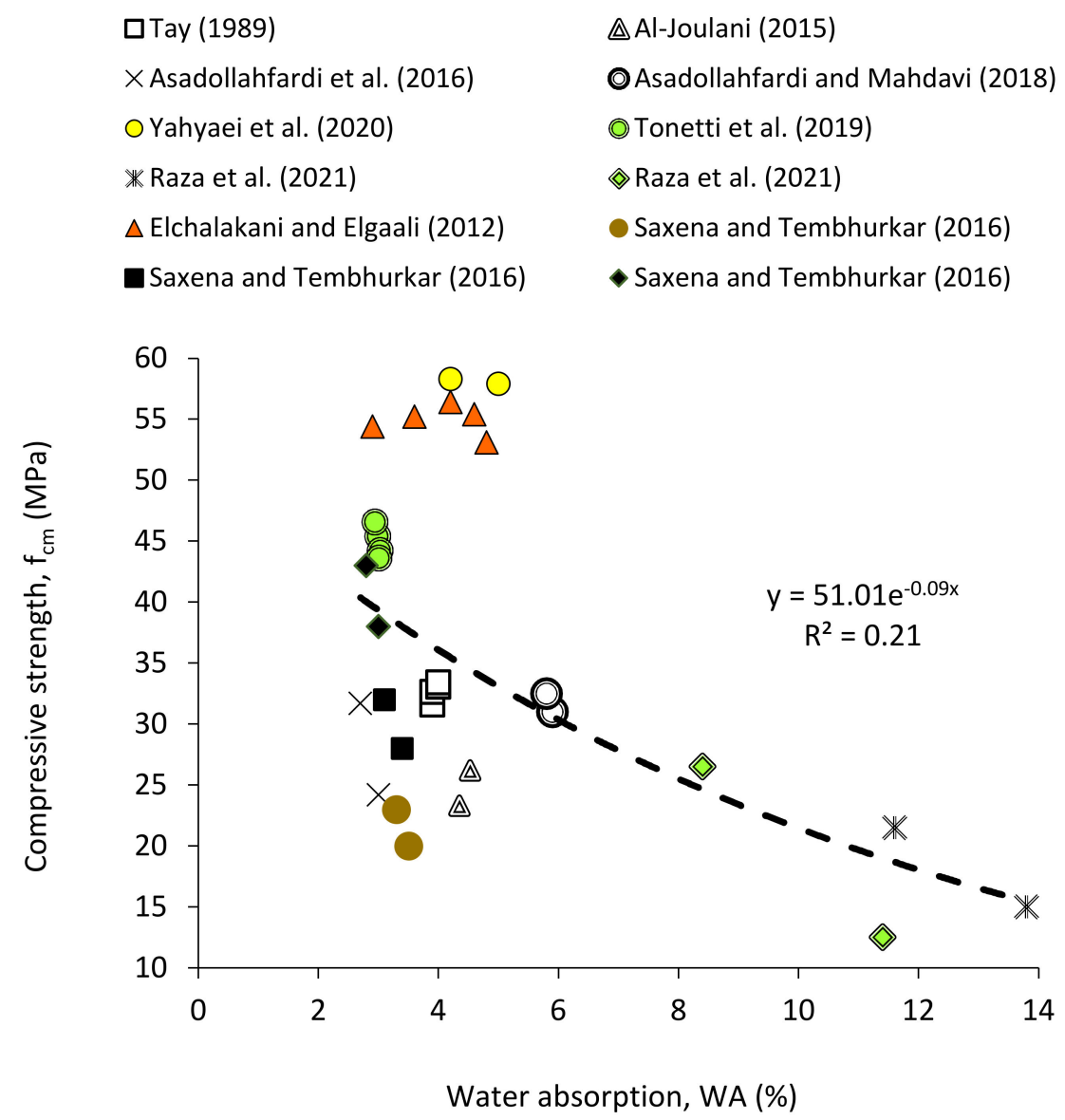

Figure 18. Relationship between compressive strength and water absorption.

Apart from the chloride ion permeability based on the charge passed, the test can be directly made either using rapid or natural chloride ion penetration for a given time. For example, the study of Raza et al. [10] investigated the effect of different types of WW on the chloride ion penetration of concrete samples immersed in a standard solution for 28 and 90 days (Figure 20). The results show that the chloride ion penetration resistance decreases in all types of WW (fertilizer factory, textile factory, sugar factory and service station) despite the fact that the compressive strength of concrete was not significantly reduced. As mentioned before, there is not enough evidence on this phenomenon, but it can be related to the fact that some of the minerals (e.g., chloride content) may not significantly affect the strength of concrete but be effective in hindering chloride ion penetration.

Generally, based on the studies $[10,15,16,24,27,38]$ in which 39 different concrete mixes were considered, the average chloride ion penetration resistance of concrete fell by $38 \%$, $25 \%, 18 \%$ and $18 \%$ with the use of untreated WW, fertilizer factory WW, textile factory WW, sugar factory WW, and service station WW, respectively, and increased by $13 \%$ with the use of treated WW. Regarding treated WW, "treated WW + bacterial solution" increased chloride ion penetration up to $71 \%$. However, this value was not considered in the conclusions because it can be considered a special case. This is because the bacterial solution microbially induces calcium carbonate precipitation in concrete by bacillus cereus that leads to reducing the water absorption and chloride ion penetration rate [27]. 


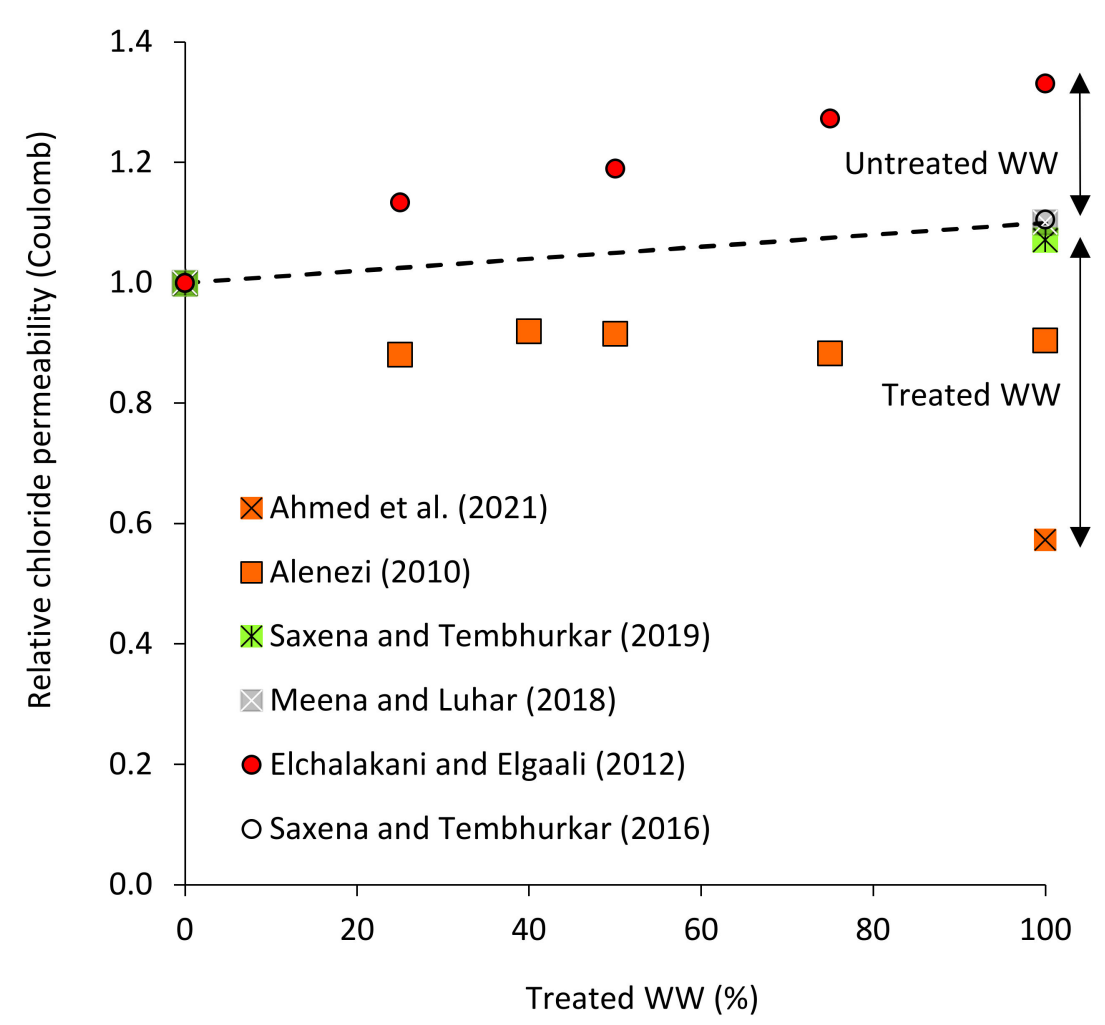

Figure 19. Relative chloride ion permeability of concrete made with treated and untraded WW.

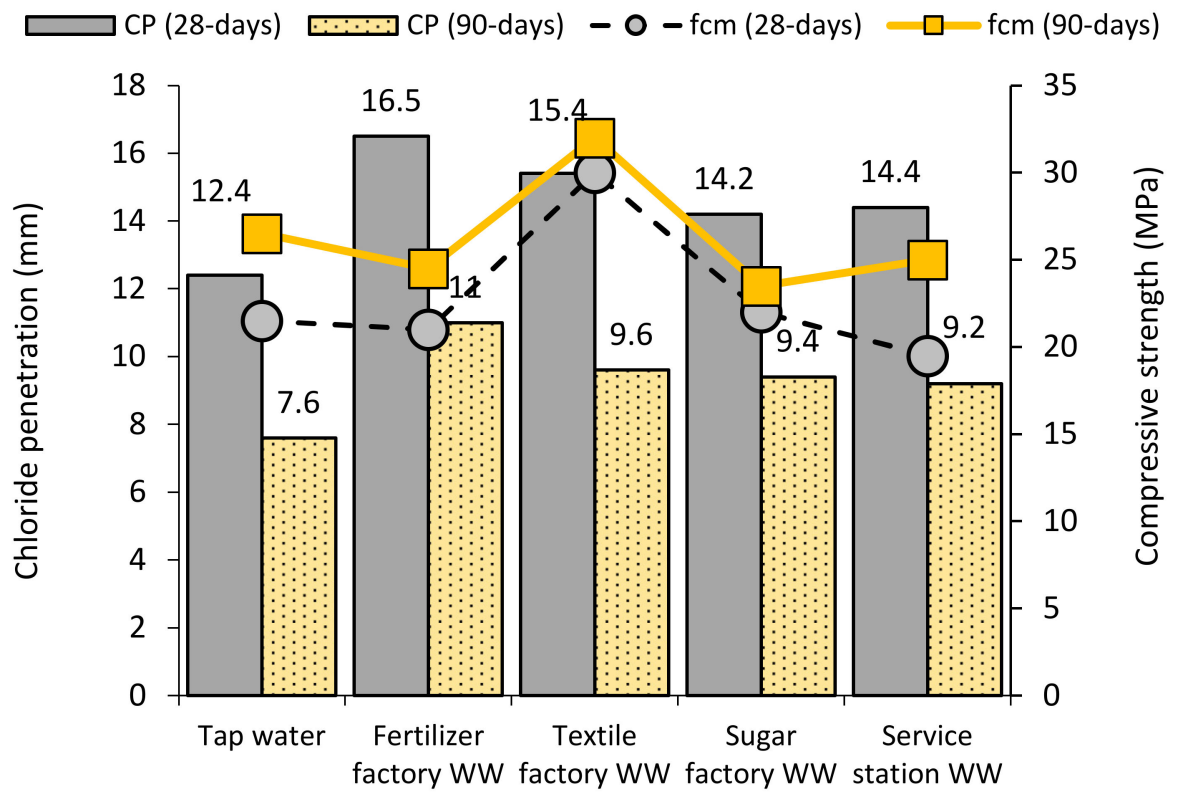

Type of water

Figure 20. Chloride ion penetration of concrete made with different types of WW.

\section{Conclusions}

This paper concerns the effect of different types and incorporation ratios of treated and untreated WW on the performance of concrete. Despite the fact that water is one of the most valuable resources, studies on this path are very scarce. In order to simplify the output of this study, the effect of the different treated and untreated WW was summarized in Figure 21. The decision (increased, decreased, and not influenced) for each property was 
made based on the average value collected from the literature. For some specific types of WW, the decision was not made because there are not many reliable studies on this subject. Thus, those can be considered as a gap requiring future studies.

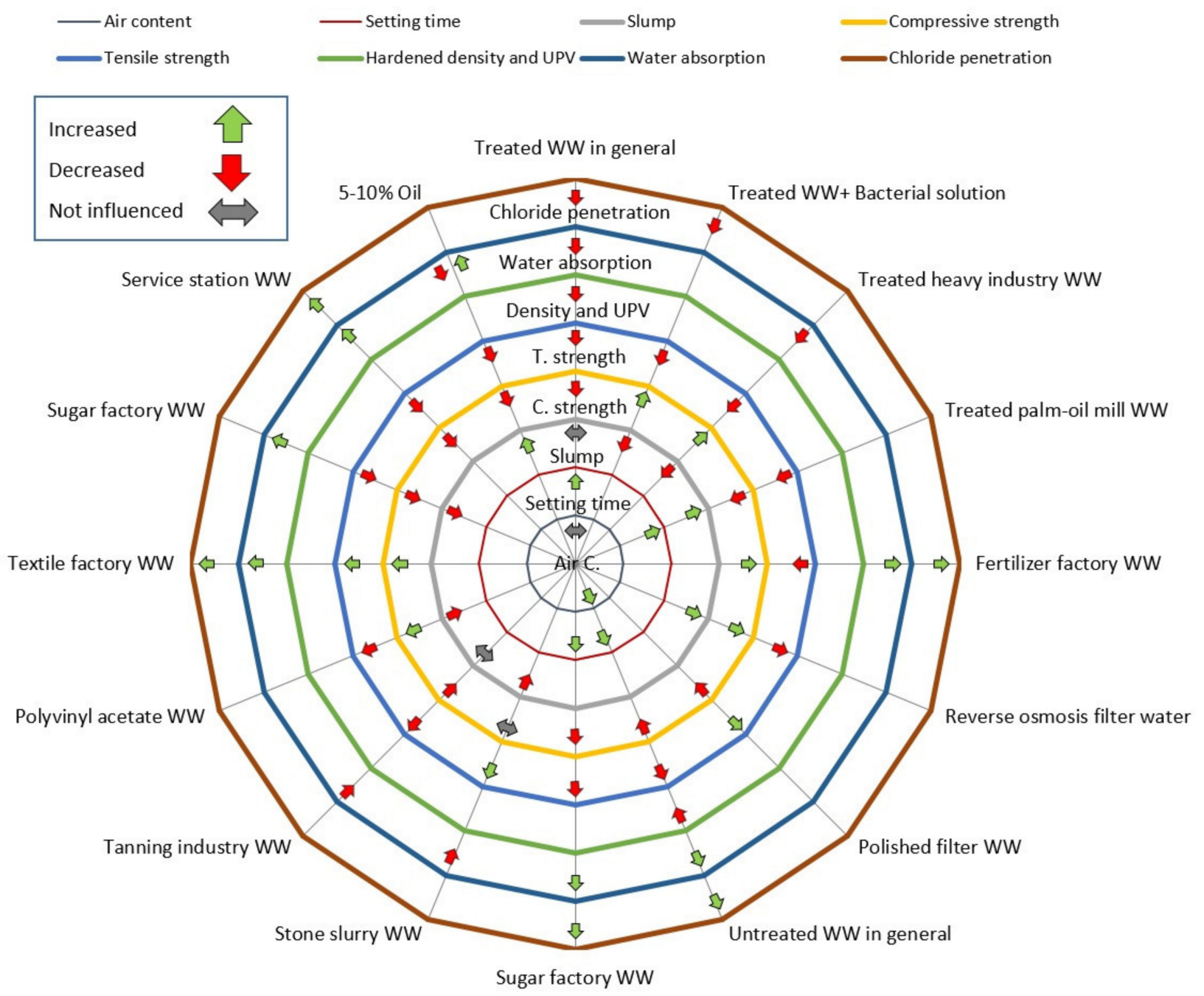

Figure 21. Effect of different types of treated and untreated WW on the performance of concrete based on the average data collected from the literature.

Generally, the slump of concrete was not reduced by the use of most types of treated and untreated WW. However, for some types of water with high electrical conduction (dissolved mineral contents), the slump falls. In addition, WW has less effect on the slump of concrete made with high $\mathrm{w} / \mathrm{c}$ than in mixes made with low $\mathrm{w} / \mathrm{c}$. Therefore, WW may not be recommended for concrete mixes made with low $\mathrm{w} / \mathrm{c}$. Furthermore, the setting time of concrete increases with the use of WW especially that containing high amounts of heavy metals such as $\mathrm{Pb}, \mathrm{Cu}$ and $\mathrm{Zn}$ or total solid concentration. Additionally, the air content of concrete increases with the use of WW but no changes have been detected from the use of treated WW.

In general, due to the presence of high amounts of organic matter, the compressive and tensile strength decrease with the use of untreated WW, especially at early ages. The change will be insignificant when the WW is treated. Nevertheless, some types of WW may not adapt to the mentioned conclusion when the chemical composition of the WW has a big scatter relative to potable water and most of WW types. For example, the presence of high percentage of fluorides, bicarbonates, salt, heavy solids, and chlorides or the water highly acidic has a huge influence. 
The results show that the effect of some WW on the performance of concrete in terms of durability is different from the mechanical strength and fresh-state properties since some of the minerals have a different effect on the physical and chemical output of cement paste. Hardened density of concrete was influenced by the treatment level of water. Available evidence showed that the density of concrete underdid a minor decrease with the rising treatment quality of WW. On the other hand, WW concrete showed smaller UPV value than equivalent tap water concrete. Nevertheless, in general, the effect of treated WW on the water absorption and chloride ion penetration of concrete is not significant, and a significant change can be seen with the use of untreated WW. Untreated WW has shown more minor increase in water absorption of concrete due to presence of high organic impurities, while the treated WW did not affect the absorption capacity. In addition, the studies show that the negative effect of WW regarding the durability aspect (except carbonation) can be offset by the use of some specific types of supplementary cementitious materials.

Author Contributions: Conceptualization, J.d.B. and R.K.; methodology, R.K. and B.A.; software, R.K. and B.A.; validation, R.K. and B.A.; formal analysis, R.K. and B.A.; investigation, R.K. and B.A.; resources, R.A., R.K. and B.A.; data curation, R.A., R.K. and B.A.; writing-original draft preparation, B.A. and R.K.; writing-review and editing, J.d.B., R.A., R.K. and B.A.; visualization, R.K. and B.A.; supervision, J.d.B.; project administration, R.K. and J.d.B. All authors have read and agreed to the published version of the manuscript.

Funding: This research received no external funding.

Acknowledgments: The authors gratefully acknowledge the support of CERIS from IST, University of Lisbon, and FCT, Foundation for Science and Technology.

Conflicts of Interest: The authors declare no conflict of interest.

\section{References}

1. Miller, S.A.; Horvath, A.; Monteiro, P.J.M. Impacts of booming concrete production on water resources worldwide. Nat. Sustain. 2018, 1, 69-76. [CrossRef]

2. Larsen, T.A.; Hoffmann, S.; Lüthi, C.; Truffer, B.; Maurer, M. Emerging solutions to the water challenges of an urbanizing world. Science 2016, 352, 928-933. [CrossRef]

3. United Nations. The World Population Prospects: 2015 Revision; United Nations Department of Economic and Social Affairs: New York, NY, USA, 2015.

4. Miller, S.A.; Horvath, A.; Monteiro, P.J.M. Readily implementable techniques can cut annual CO2 emissions from the production of concrete by over 20\%. Environ. Res. Lett. 2016, 11, 74029. [CrossRef]

5. Silva, M.; Naik, T.R. Sustainable use of resources-recycling of sewage treatment plant water in concrete. In Proceedings of the Second International Conference on Sustainable Construction Materials and Technologies, Ancona, Italy, 28 June 2010; Volume 28.

6. Peighambarzadeh, F.S.; Asadollahfardi, G.; Akbardoost, J. The effects of using treated wastewater on the fracture toughness of the concrete. Aust. J. Civ. Eng. 2020, 18, 56-64. [CrossRef]

7. Rodrigues, P.; Silvestre, J.D.; Flores-Colen, I.; Viegas, C.A.; De Brito, J.; Kurad, R.; Demertzi, M. Methodology for the assessment of the ecotoxicological potential of construction materials. Materials 2017, 10, 649. [CrossRef]

8. CCAA. Use of Recycled Water in Concrete Production; CCAA Cement Concrete and Aggregates Australia: Sydney, Australia, 2007; Volume 27.

9. Noruzman, A.H.; Muhammad, B.; Ismail, M.; Abdul-Majid, Z. Characteristics of treated effluents and their potential applications for producing concrete. J. Environ. Manag. 2012, 110, 27-32. [CrossRef] [PubMed]

10. Raza, A.; Rafique, U.; ul Haq, F. Mechanical and durability behavior of recycled aggregate concrete made with different kinds of wastewater. J. Build. Eng. 2021, 34, 101950. [CrossRef]

11. Daryaee, M.; Bijanvand, S. Effects of Sugarcane Wastewater Utilization in Concrete Fabrication for Irrigation Channel Coverage. J. Irrig. Sci. Eng. 2021, 43, 15-22.

12. Arooj, M.F.; Haseeb, F.; Butt, A.I.; Irfan-Ul-Hassan, M.; Batool, H.; Kibria, S.; Javed, Z.; Nawaz, H.; Asif, S. A sustainable approach to reuse of treated domestic wastewater in construction incorporating admixtures. J. Build. Eng. 2021, 33, 101616. [CrossRef]

13. Al-Joulani, N.M.A. Effect of wastewater type on concrete properties. Int. J. Appl. Eng. Res. 2015, 10, 39865-39870.

14. Ismail, Z.Z.; Al-Hashmi, E.A. Assessing the recycling potential of industrial wastewater to replace fresh water in concrete mixes: Application of polyvinyl acetate resin wastewater. J. Clean. Prod. 2011, 19, 197-203. [CrossRef]

15. Alenezi, N. Evaluation and Assessment of Concrete Produced by Utilizing of Treated Wastewater. In Proceedings of the Concrete Sustainability Conference, Kuwait City, Kuwait, 1-9 December 2010. 
16. Elchalakani, M.; Elgaali, E. Sustainable concrete made of construction and demolition wastes using recycled wastewater in the UAE. J. Adv. Concr. Technol. 2012, 10, 110-125. [CrossRef]

17. Sultana, I.; Islam, G.M.S. Applicability Of Treated Industrial Wastewater In Concrete Industry. In Proceedings of the 1st International Conference on Research and Innovation in Civil Engineering (ICRICE 2018), Chittagong, Bangladesh, 12-13 January 2018.

18. Gadzama, E.W.; Ekele, O.J.; Anametemfiok, V.E.; Abubakar, A.U. Effects of Sugar Factory Wastewater as Mixing Water on the Properties of Normal Strength Concrete; Civil Engineering Department. Modibbo Adama University of Technology, PMB: Modibbo, Nigeria, 2015; Volume 2076, pp. 2-3.

19. Tay, J.-H. Reclamation of wastewater and sludge for concrete making. Resour. Conserv. Recycl. 1989, 2, 211-227. [CrossRef]

20. El-Nawawy, O.A.; Ahmad, S. Use of treated effluent in concrete mixing in an arid climate. Cem. Concr. Compos. 1991, 13, 137-141. [CrossRef]

21. Ghrair, A.M.; Al-Mashaqbeh, O.A.; Sarireh, M.K.; Al-Kouz, N.; Farfoura, M.; Megdal, S.B. Influence of grey water on physical and mechanical properties of mortar and concrete mixes. Ain Shams Eng. J. 2018, 9, 1519-1525. [CrossRef]

22. Chatveera, B.; Lertwattanaruk, P.; Makul, N. Effect of sludge water from ready-mixed concrete plant on properties and durability of concrete. Cem. Concr. Compos. 2006, 28, 441-450. [CrossRef]

23. Asadollahfardi, G.; Delnavaz, M.; Rashnoiee, V.; Ghonabadi, N. Use of treated domestic wastewater before chlorination to produce and cure concrete. Constr. Build. Mater. 2016, 105, 253-261. [CrossRef]

24. Saxena, S.; Tembhurkar, A.R. Impact of use of steel slag as coarse aggregate and wastewater on fresh and hardened properties of concrete. Constr. Build. Mater. 2018, 165, 126-137. [CrossRef]

25. Hassani, M.S.; Asadollahfardi, G.; Saghravani, S.F.; Jafari, S.; Peighambarzadeh, F.S. The difference in chloride ion diffusion coefficient of concrete made with drinking water and wastewater. Constr. Build. Mater. 2020, 231, 117182. [CrossRef]

26. Kaboosi, K.; Emami, K. Interaction of treated industrial wastewater and zeolite on compressive strength of plain concrete in different cement contents and curing ages. Case Stud. Constr. Mater. 2019, 11, e00308. [CrossRef]

27. Saxena, S.; Tembhurkar, A.R. Developing biotechnological technique for reuse of wastewater and steel slag in bio-concrete. $J$. Clean. Prod. 2019, 229, 193-202. [CrossRef]

28. Meena, K.; Luhar, S. Effect of wastewater on properties of concrete. J. Build. Eng. 2019, 21, 106-112. [CrossRef]

29. Babu, G.R.; Ramana, N.V. Feasibility of wastewater as mixing water in cement. Mater. Today Proc. 2018, 5, 1607-1614. [CrossRef]

30. Mahasneh, B.Z. Assessment of replacing wastewater and treated water with tap water in making concrete mix. Electron. J. Geotech. Eng. 2014, 19, 2379-2386.

31. Asadollahfardi, G.; Mahdavi, A.R. The feasibility of using treated industrial wastewater to produce concrete. Struct. Concr. 2019, 20, 123-132. [CrossRef]

32. Yahyaei, B.; Asadollahfardi, G.; Salehi, A.M. Workability, mechanical, and durability properties of self-compacting concrete using the treated wastewater. Struct. Concr. 2021, 22, E997-E1008. [CrossRef]

33. Duarte, N.C.; Amaral, A.E.d.S.; Gomes, B.G.L.A.; Siqueira, G.H.; Tonetti, A.L. Water reuse in the production of non-reinforced concrete elements: An alternative for decentralized wastewater management. J. Water Sanit. Hyg. Dev. 2019, 9, 596-600. [CrossRef]

34. Tonetti, A.L.; Duarte, N.C.; dos Santos, M.R.R.; Siqueira, G.H. Environmentally friendly interlocking concrete paver blocks produced with treated wastewater. Water Supply 2019, 19, 2028-2035. [CrossRef]

35. Al-Jabri, K.S.; Al-Saidy, A.H.; Taha, R.; Al-Kemyani, A.J. Effect of using wastewater on the properties of high strength concrete. Procedia Eng. 2011, 14, 370-376. [CrossRef]

36. Shekarchi, M.; Yazdian, M.; Mehrdadi, N. Use of biologically treated domestic waste water in concrete. Kuwait J. Sci. Eng. 2012, 39, 97-111.

37. Tay, J.-H.; Yip, W.-K. Use of reclaimed wastewater for concrete mixing. J. Environ. Eng. 1987, 113, 1156-1161. [CrossRef]

38. Ahmed, S.; Alhoubi, Y.; Elmesalami, N.; Yehia, S.; Abed, F. Effect of recycled aggregates and treated wastewater on concrete subjected to different exposure conditions. Constr. Build. Mater. 2021, 266, 120930. [CrossRef]

39. Al-Ghusain, I.; Terro, M. Use of treated wastewater for concrete mixing in Kuwait. Kuwait J. Sci. Eng. 2003, 30, $213-228$.

40. ASTM T26-79. Standard Test Method for Quality of Water to Be used in Concrete; ASTM International: West Conshohocken, PA, USA, 1996.

41. Terro, M.; Al-Ghusain, I. Mechanical properties of concrete made with treated wastewater at ambient and elevated temperatures. Kuwait J. Sci. Eng. 2003, 30, 229-244.

42. Babu, G.R.; Reddy, B.M.; Ramana, N.V. Quality of mixing water in cement concrete "a review". Mater. Today Proc. 2018, 5, 1313-1320. [CrossRef]

43. Mindess, S.; Young, J.F.; Darwin, D. Concrete Prentice-Hall. Englewood Cliffs NJ 1981, 481, 339-348.

44. BS EN 1008:2002. Mixing Water for Concrete—Specification for Sampling, Testing and Assessing the Suitability of Water, including Water Recovered from Processes in the Concrete Industry, as Mixing Water for Concrete; British Standards Institution: London, UK, 2002.

45. Hefni, Y.; El Zaher, Y.A.; Wahab, M.A. Influence of activation of fly ash on the mechanical properties of concrete. Constr. Build. Mater. 2018, 172, 728-734. [CrossRef] 
46. EN-1992-1-1 Eurocode 2-Design of Concrete Structures. Part 1-1: General Rules and Rules for Buildings; CEN: 259; The European Union: Brussels, Belgium, 2008.

47. Venkateswara, R.; Kontham, G.; Venkata, R.; Chundupalli, S. Effect of potassium chloride (KCl) on ordinary Portland cement (OPC) concrete. Res. J. Chem. Sci. 2011, 1, 103-107. 